This is a post-refereed, pre-print version of an article which appeared in 20 Max Planck Yearbook of United Nations Law (2017)

https://doi.org/10.1163/13894633_02001008

\title{
The Status and Criminal Accountability of Members of Formed Police Units: Conflicting Positions, Current Status Quo and Future Prospects
}

\author{
Zsuzsanna Deen-Racsmány
}

\begin{abstract}
Introduced in 1999, Formed Police Units constitute a relatively recent invention in the history of UN peacekeeping. Yet, currently more than 10,000 individuals are deployed in such units. Their members are UN civilian police officers but - like military personnel - they may be given executive mandates. Consequently, (the optimal regulation of) their legal position (whether equivalent to that of military members of national contingents or of UN experts on mission) and (of) their criminal accountability (exclusive contributing State jurisdiction and/or permissibility of host State criminal jurisdiction) have been a subject of prolonged disagreement. The legal-political struggle between the UN Secretariat (Office of Legal Affairs) and the Special Committee on Peacekeeping Operations concerning these issues has triggered important clarifications of the existing rules and led to revisions of legal instruments, including the most recent amendments to the UN Model Memorandum of Understanding.

Through a study of this process, the present article aims to clarify the legal status and criminal accountability of FPU officers, as well as to predict the stability of the current legal status quo. In addition, the analysis of these issues provides valuable insights into the relevant practice of and priorities within the UN and among troop and police contributing countries. It thus even helps assess chances that military members of national contingents may in the future be subjected to the criminal jurisdiction of host States. Last but not least, the study highlights the importance of accurate and up-to-date information.
\end{abstract}

\section{Keywords}

Criminal accountability - experts on mission - formed police units - Memorandum of Understanding - military members of national contingents - Special Committee on Peacekeeping Operations - UN peacekeeping - UN Police

\section{Introduction}


Whereas civilian police personnel have formed part of United Nations (UN) field missions since 1960, formed police units (FPUs) have been utilized for less than two decades. ${ }^{1}$ Today, FPU officers - amounting to about seventy percent of all police personnel currently deployed by the $\mathrm{UN}^{2}$ - constitute one of the largest personnel categories (next only to military members of national contingents (MMsNCs) and to local civilian personnel) in UN peacekeeping operations. $^{3}$

In introducing formed police units in the UN (peacekeeping) system, existing personnel categories were apparently taken as examples, and legal arrangements applicable to those were followed to the extent feasible and justified by the characteristics of FPU officers and by the nature of their functions. However, members of FPUs constitute a Janus-faced group, resembling in significant respects two distinct personnel categories employed in UN peacekeeping operations: experts on mission and MMsNCs. They are UN civilian police (CIVPOL) officers. Accordingly, their overall status is similar to that of individually seconded UN (civilian) police personnel (individual police officers or IPOs) who are unanimously recognized to have the status of experts on mission for the United Nations. However, FPUs' mandate - while in essence similar to the traditional CIVPOL tasks - may involve the use of firearms and executive functions usually preserved for military personnel. In addition, the manner and structure wherein they are contributed to the UN resembles the contribution of military contingents by member States. ${ }^{4}$ However, the status, immunities and criminal accountability of IPOs differ significantly from the relevant rules applicable to MMsNCs. ${ }^{5}$ For inter alia these reasons, (the optimal regulation of) the status of members of FPUs and the extent and holders of criminal and disciplinary authority over them have been subject of protracted debate.

In spite of such controversies and of the fact that FPUs have become a central factor in UN peacekeeping, legal scholarship has shown very little interest in (members of) formed police units and in particular in their status, immunities and criminal accountability. ${ }^{6}$ In contrast, these issues have been contentious for over a decade between troop and police contributing countries (TCCs and PCCs) (members of the UN General Assembly's Special Committee on Peacekeeping Operations $(\mathrm{C}-34)^{7}$ ) and the UN (Secretariat). The position of the

\footnotetext{
${ }^{1}$ See Section II, infra.

${ }^{2}$ S. Sebastián, The Role of Police in UN Peace Operations: Filling the Gap in the Protection of Civilians from Physical Violence, Civilians in Conflict, Policy Brief No. 3 (Stimson Center, 2015) 11.

3 See fact sheets on 'United Nations Peacekeeping Operations' $<$ http://www.un.org/en/peacekeeping/resources/statistics/factsheet.shtml> and the UN Police website on FPUs at $<$ http://www.un.org/en/peacekeeping/sites/police/units.shtml>.

${ }^{4}$ See Section II, infra, for further details.

${ }^{5}$ See Section III.1, infra.

${ }^{6}$ These issues are, however, addressed in relation to UN civilian police personnel in general in e.g. A.J. Miller, 'United Nations Experts on Mission and their Privileges and Immunities' (2007) 4 IOLR 11 and B. Oswald and A. Bates, 'Privileges and Immunities of United Nations Police' (2010) 14 Journal of International Peacekeeping 375. The latter study and another work published by the same authors touch upon some of these issues in relation to FPU officers in particular but do so in passing. See Oswald and Bates, 'Privileges and Immunities of United Nations Police' 390, positing without any discussion or explanation that all UN police personnel, including members of FPUs, are granted the status of experts on mission under UN status of forces agreements, and B. Oswald, H. Durham and A. Bates, Documents on the Law of UN Peace Operations (OUP 2010) 392, n. 3 and accompanying text, noting the applicability of the current version of the Department of Peacekeeping Operations (DPKO) 'Directives for Disciplinary Matters Involving Civilian Police Officers and Military Observers' (July 2003) UN Doc DPKO/CPD/DDCPO/2003/001, as amended by Code Cable 2697 of 7 October 2005 $<$ http://www.pseataskforce.org/en/tools> to members FPUs. On this development, see Section IV.2, infra. See also Oswald, Durham and Bates, Documents on the Law of UN Peace Operations 35 on the status of FPUs.

7 The Special Committee was established by the General Assembly (UNGA) in 1965 to undertake a comprehensive review of all issues relating to UN peacekeeping and to report on those to it. It consists of 147 member States, mainly past or current troop-contributors. Fourteen additional UN member States and some
} 
main actors was clear from the beginning: the UN considered FPU officers, like other CIVPOL personnel, as experts on mission for the Organization, protected by immunities ratione materiae but in certain cases subject to host State criminal jurisdiction. In contrast, the C-34 emphasized similarities with MMsNCs and insisted on granting PCCs exclusive criminal jurisdiction over FPU officers (and in fact over CIVPOL personnel in general).

This struggle resulted in some significant changes, and the official position moved back and forth. In addition, information published and legal documents and reports adopted by various UN organs and bodies have not always been up-to-date or accurate in terms of their position on these issues. ${ }^{8}$ As a result, a quick review of existing UN materials may blur the already unclear picture even further. The effect: uncertainty and ambiguity, to the extent that in the past over a decade it may at times have proven somewhat of a challenge to come to a correct conclusion regarding the legal status and criminal accountability of FPU officers. ${ }^{9}$

However, these issues are not inconsequential: not only do FPU officers constitute a considerable share of all UN field personnel (with over 10,000 individuals!) ${ }^{10}$, they are also implicated in a significant percentage of recent accusations of sexual exploitation and abuse $(\mathrm{SEA})^{11}$ allegedly involving UN mission personnel. ${ }^{12}$ In addition, these issues gain additional

intergovernmental organizations and entities, including regional organizations as well as the International Committee of the Red Cross and the International Criminal Police Organization, participate as observers. (<http://www.un.org/en/peacekeeping/ctte/CTTEE.htm>)

${ }^{8}$ For instance, the DPKO/Department of Field Support (DFS) Civil Affairs Handbook (UN 2012) Ref. 2012.02, 43) distinguishes between IPOs, “who are 'experts on mission' and generally unarmed” (emphasis added) and (armed) FPUs. The distinction gives the impression that FPU members are not experts on mission. In contrast, the DPKO, Police Division 'Guidelines for Formed Police Units on Assignment with Peace Operations' (8 May 2006) UN Doc DPKO/PD/2006/00015, paras. 14 and 30) clearly confirm the status of members of FPUs as experts on mission and the applicability of relevant immunities to them, even recognizing the right of the host State to exercise criminal jurisdiction over them. The inconsistency between these publications cannot be explained with reference to legal developments between 2006 and 2012. See Sections IV.2.-IV.3, infra.

In addition, whereas the 2006 'Guidelines for Formed Police Units on Assignment with Peace Operations' 7, n. 3, refer - discussing disciplinary matters - to the fact that the 'Directives for Disciplinary Matters Involving Civilian Police Officers and Military Observers' had been amended to apply to FPUs, it does not alert the reader to this fact in its Annex 11 (containing the original text of the Directives which denied the applicability of this instrument to members of FPUs). On these amendments, see text accompanying notes 109110, infra.

Similarly, the website of the UN's Conduct and Discipline Unit still contains a version of the 'Directives for Disciplinary Matters Involving Civilian Police Officers and Military Observers’ prior to its 2005 amendment (<https://cdu.unlb.org/Portals/0/PdfFiles/PolicyDocG.pdf $>$ ). See also notes 149-150 and accompanying text, infra, on the failure within the UN and of other relevant actors to note relevant changes and to update information.

${ }^{9}$ For instance, a fact sheet on 'Privileges and Immunities of the United Nations' published by the Code Blue Campaign ((13 May 2005) <http://www.codebluecampaign.com/fact-sheets-materials/2015/5/13/immunity>) states that "[w] hile UN documents are not entirely clear, our research indicates that both Formed Police Units and UN civilian police are classified as Experts on Mission” (emphasis added). Code Blue is an influential civil society project. It repeatedly attracted the attention of international media in the past year, pressing for more transparency concerning and accountability for sexual exploitation and abuse committed by UN peacekeepers.

10 See UNPOL website.

${ }^{11}$ According to statistics presented by the UN Secretary-General, SEA-related accusations received against FPU officers amounted to 7,2 \% of all such accusations (5 of 69) in 2015 (UNGA 'Report of the Secretary-General: Special Measures for Protection from Sexual Exploitation and Sexual Abuse' (16 February 2016) UN Doc A/70/729 (hereinafter Secretary-General 'Special Measures Report' 2016)), whereas FPUs constituted about eight percent of all UN peacekeeping personnel (see sources cited in note 3, supra, cf. text accompanying note 20, infra).

12 In the past decades, SEA has become a major problem in UN peacekeeping, affecting the credibility of the UN. The fight against SEA in UN missions has thus featured high on international agenda's and the UN has been attempting to tackle the problem for over a decade. For further information on this issue, see, e.g. $<$ http://legal.un.org/committees/criminal_accountability/>, $\quad<$ https://cdu.unlb.org/> and $<$ http://www.un.org/en/ga/sixth/70/criminal_accountability.shtml>. 
importance now, at a moment that exclusive TCC criminal jurisdiction over MMsNCs becomes drawn into question even in UN circles. ${ }^{13}$ For these reasons, this article aims to clarify the current status of members of FPUs as well as the rules governing their criminal accountability and to assess the likelihood of change. To provide for a better understanding of the presently unambiguous legal situation, we will approach these issues through the looking glass of the developments that have led to the current status quo.

The study will start out with a short description of UN (civilian) police and FPUs, paying attention to their origins, tasks and main characteristics. Next, it will provide a brief overview of the original rules concerning the legal status, privileges and immunities, and criminal accountability of CIVPOL (experts on mission for the UN), MMsNCs and FPU officers in broad lines. The main body of the article examines the struggle between the C-34 and the UN (Secretariat), both sturdy in their respective views and sentiments. Through presenting both positions and relevant developments, the author offers gradually to clarify the central issues of this study: the status and criminal accountability of FPU officers. The last substantive section addresses the likelihood that the current status quo represents a final solution. The article concludes with a summary of the findings and presents some lessons learned and implications for the criminal accountability of MMsNCs.

\section{From CIVPOL to UNPOL and the Birth of FPUs}

The first civilian ${ }^{14}$ police officers were deployed by the UN in the United Nations Operation in the Congo between 1960-1964. ${ }^{15}$

In the early days, they were

to undertake the supervision or control of local civil police in order to ensure that law and order are maintained effectively and impartially, and that the human rights and fundamental freedoms are fully protected. ${ }^{16}$

Over the decades, their tasks evolved, "from monitoring and advising functions to reforming, restructuring and institution building of local police services and performing executive law enforcement". ${ }^{17}$ In addition, UN police may be involved in election monitoring and assisting humanitarian agencies. ${ }^{18}$

\footnotetext{
13 See text accompanying notes 171-172, infra.

14 The specific reference here to the "civilian" nature of such personnel distinguishes these individuals from "military police”. The latter category serves in UN peacekeeping missions with the aim to "police the premises" of the mission and "to maintain discipline and order" among its members (UNGA "Report of the SecretaryGeneral: Model Status-of-Forces Agreement for Peace-Keeping Operations' (9 October 1990) UN Doc A/45/594, Annex (hereinafter Model SOFA), para. 40, see also ibid., para. 41). The tasks of “military police” are thus centered within, rather than outside the mission. Unless specifically stated otherwise, references in this study to (UN) police personnel concern civilian police.

15 DPKO Handbook on United Nations Multidimensional Peacekeeping Operations (UN 2003) 84; UNGA 'Report of the Secretary-General: United Nations police' (15 December 2011) UN Doc A/66/615, para. 9. However, the 'Agreement between the United Nations and the Republic of the Congo relating to the Legal Status, Facilities, Privileges and Immunities of the United Nations Organization in the Congo' (27 November 1961) UN Doc A/4986-S/5004 and the 'Regulations for the United Nations Force in the Congo' (15 July 1963) UN Doc ST/SGB/ONUC/1 do not specifically mention UN civilian police.

${ }^{16}$ DPKO United Nations Civilian Police Handbook (UN 1995) 9-10.

17 DPKO Handbook on United Nations Multidimensional Peacekeeping Operations 83. See also UNSC Res 2185 (2014) 'United Nations Police’ (20 November 2014) UN Doc S/RES/2185 (2014), preambular para. 12. For more detailed information on these tasks, see DPKO/DFS 'Policy on United Nations Police in Peacekeeping Operations and Special Political Missions’ (1 February 2014) Ref. 2014.01 12-20.

${ }^{18}$ DPKO United Nations Civilian Police Handbook 31.
} 
Corresponding to their broadening and increasingly complex tasks, police personnel constitutes the "fastest growing component within United Nations peacekeeping operations." ${ }^{\prime 19}$ A major part of this growth is attributable to FPUs: at the time of writing, 71 units were deployed, involving over 10,000 FPU officers. ${ }^{20}$

Their extensive deployment and crucial contribution to UN peacekeeping have led to calls for a more professional attitude to UN police matters, from recruitment to implementing assignments. ${ }^{21}$ To emphasize the shift in their functions and to provide them with a new image, even the name was changed from UN civilian police (or CIVPOL) to UN Police (UNPOL) in 2005. ${ }^{22}$ Yet, many UN documents and instruments governing, for instance, their legal status or disciplinary matters still refer to "civilian police", probably as a factual description. ${ }^{23}$ In addition, it is clear that - at least with regard to suitable equipment, training and selection - there is still room within UNPOL for improvement. ${ }^{24}$

Even more relevantly for the present study, UN practice related to the utilization of police personnel underwent a significant relatively recent change. Whereas initially all police officers were seconded individually, since 1999 the Organization has increasingly deployed, next to individual police officers, also Formed Police Units. ${ }^{25}$

FPUs have three core tasks: public order management, protection of United Nations personnel and facilities, and support for police operations that may involve a higher risk above the general capability of an IPO. ${ }^{26}$

FPUs are "cohesive mobile police units", ${ }^{27}$ consisting of about 120-140 officers of one nationality. ${ }^{28}$ Their members, like IPOs, are active or retired police officers in their home

19 A-M. Orler, 'Professionalising United Nations Police In Peacekeeping: Vision for the Police Division and United Nations Police in Peacekeeping' (September $<$ http://www.un.org/en/peacekeeping/sites/police/documents/unpol_vision.pdf > . For exact participation figures (past and present), see 'United Nations Peacekeeping Operations' fact sheets.

${ }^{20}$ See UN Police website on FPUs.

21 Orler, 'Professionalising United Nations Police In Peacekeeping'. The importance of UN Police, their significant contribution to UN peacekeeping, their growth and increasing diversification were recently acknowledged even by the Security Council (see UNSC Res 2185 'United Nations Police’ Preamble).

${ }^{22}$ See <http://www.un.org/en/peacekeeping/sites/police/new_identity.shtml>.

${ }^{23}$ E.g. para. 26 Model SOFA; 'Directives for Disciplinary Matters Involving Civilian Police Officers and Military Observers'. See also note 14, supra on the distinction between civilian and military police.

${ }^{24}$ See e.g. UNSC Res 2185 ‘United Nations Police’ preambular para. 16; paras. 3 and 31; UNGA 'United Nation police’ paras. 62, 67; H.F. Johnson, 'Capacity to Protect Civilians: Rhetoric or Reality?’ Challenges Forum, Policy Brief 2015:4 <http://www.challengesforum.org/en/Reports--Publications/CF/POLICY-BRIEF-20154/> 9; UNGA 'Report of the Secretary-General: The future of United Nations peace operations: implementation of the recommendations of the High-level Independent Panel on Peace Operations' (2 September 2015) UN Doc A/70/357-S/2015/682, paras. 93 and 24.

${ }^{25}$ The first FPUs were deployed within the United Nations Mission in Kosovo (UNMIK) and the United Nations Transitional Administration in East Timor (UNTAET). See UN Police website on FPUs. Both missions were deployed without a status of forces agreement (see e.g. I. Ingravallo, 'UN Territorial Administrations: Between International Humanitarian Law and Human Rights Law’ in R. Kolb and G. Gaggioli (eds), Research Handbook on Human Rights and Humanitarian Law (Elgar 2013) 391, $411 \mathrm{n} .97$ ), hence it is not possible to identify the status and criminal accountability of FPU officers specifically in these contexts based on such agreements.

It may be noted that a third - relatively minor - category of UNPOL personnel serve as UN staff members. See 'United Nations Police Selection and Recruitment Kit' < http://womenspolicenetwork.org/wpcontent/uploads/2013/08/UNPOL-Selection-and-Recruitment-Kit-September-2012_web.pdf> Preface 3.

26 'United Nations Police Selection and Recruitment Kit' Preface 3, para. 20, footnote omitted. See also DPKO/DFS 'Policy on Formed Police Units in United Nations Peacekeeping Operations' (revised) (2010) Ref. 2009.32, para. 12.

27 DPKO/DFS 'Guidelines on Police Operations in United Nations Peacekeeping Operations and Special Political Missions’ (2015) Ref. 2015.15 25. 
countries, contributed by member States to the United Nations at the Secretary-General's request. $^{29}$

The rules and practices related to their secondment to the UN follow a pattern representing a mixture between those utilized in relation to IPOs (and in general UN experts on mission) on the one hand, and to MMsNCs on the other. First, FPU officers do not sign a contract with the UN. Like MMsNCs but in contrast to IPOs ${ }^{30}$, they are not contracted or seconded individually to the UN by the seconding State. Rather, they are contributed in units under a Memorandum of Understanding (MOU) ${ }^{31}$ concluded between the UN and the PCC. ${ }^{32}$

In addition, like MMsNCs, FPU members are armed and may have enforcement capacities and executive mandates. ${ }^{33}$ These facts evidence a significant parallel with MMsNCs. It should however be noted that although CIVPOL $^{34}$ and in particular FPU personnel bear (light) arms ${ }^{35}$ and "are equipped to convey a stronger presence than a collection of individual police officers", "they seldom have the power to arrest or enforce". ${ }^{36}$ In other words, FPU officers should be "capable of handling an escalating security situation, where, for example, a demonstration turns violent, but FPUs are not an extension of the military peacekeepers". ${ }^{37}$ Moreover, executive task are exceptional today. ${ }^{38}$

28 'Policy on Formed Police Units in United Nations Peacekeeping Operations', paras. 20-21; UN Peacekeeping PDT Standards, Core Pre-Deployment Training Materials (1st ed., 2009) Unit 2 <http://www.peacekeepingbestpractices.unlb.org/PBPS/Pages/Public/Download.aspx?docid=936> 52; DPKO/DFS Civil Affairs Handbook 43.

${ }^{29}$ UN Peacekeeping PDT Standards 52; 2006 'Guidelines for Formed Police Units on Assignment with Peace Operations’ 5, para. 14 (specifically in relation to members of FPUs). H.F. Johnson, A. Wafy, M. Kroeker, J. Rauch, B. Ahmed and S. Rumin 'External Review of the Functions, Structure and Capacity of the UN Police Division’ (31 May 2016) < http://www.un.org/en/peacekeeping/documents/policereview2016.pdf>, para. 165.

${ }^{30}$ See e.g. 'Guidelines on Police Operations in United Nations Peacekeeping Operations and Special Political Missions’ 7, para. 20.

${ }^{31}$ On these agreements, see briefly Section III.1., infra, and Zs. Deen-Racsmány, 'The Amended UN Model Memorandum of Understanding: A New Incentive for States to Discipline and Prosecute Military Members of National Peacekeeping Contingents?’ (2011) 16 Journal of Conflict and Security Law 321.

32 'Policy on Formed Police Units in United Nations Peacekeeping Operations' para. 9. Until recently, a single model MOU was used for contributing military contingents and FPUs. See, however, Section IV.4, infra on relevant recent amendments

${ }^{33}$ See DPKO, United Nations Police Handbook (UN 2005) 41-42. See also para. 37 Model SOFA.

${ }^{34}$ The C-34 has repeatedly emphasized in relation to the entire category of UN civilian police that they may need to carry out executive mandates similar to those assigned to MMsNCs. However, such tasks appear to have been reserved for FPUs. See Sebastián, The Role of Police in UN Peace Operations: Filling the Gap in the Protection of Civilians From Physical Violence 21-22 and 49 n. 76. Indeed, the first instances of CIVPOL personnel being mandated executive functions concerned the first deployments of FPUs (in UNMIK and UNTAET) and few such mandates followed. See note 25, supra and note 38, infra.

${ }^{35}$ Sebastián, The Role of Police in UN Peace Operations: Filling the Gap in the Protection of Civilians From Physical Violence 12.

${ }^{36}$ H.P. Langille, Improving United Nations Capacity for Rapid Deployment (International Peace Institute, October 2014) < <ttps://www.ipinst.org/wpcontent/uploads/publications/ipi_e_pub_improving_un_rapid_deployment.pdf > 7-8.

${ }^{37}$ A.S. Hansen, 'Policing the Peace: The Rise of United Nations Formed Police Units' ZIF Policy Briefing (May 2011) Berlin: Centre for International Peace Operations 2.

${ }^{38}$ As noted by Sebastián,

[s]ince the experiences in Kosovo and Timor Leste, executive mandates have been rarely authorized as a result of political sensitivities about host-state sovereignty and the operational challenges associated with this kind of mandate for UN police.

Sebastián, The Role of Police in UN Peace Operations: Filling the Gap in the Protection of Civilians From Physical Violence 9 see also ibid., 10, 21-22, 49 n. 76 and DPKO, United Nations Police Handbook 51. On the complexity of problems raised by executive mandates, see e.g. DKPO, United Nations Civilian Police Principles and 
On the other hand, there are some significant dissimilarities between FPU officers and MMsNCs. First, FPUs are administratively clearly separated from national military contingents in terms of structure and chain of command: FPUs (like other UNPOL personnel) are not part of the military component of the operation to which they are assigned. Instead, they (together with IPOs) form a separate (police) component, headed by the Head of Police Components. ${ }^{39}$ These features emphasize that, unlike MMsNCs, FPU officers constitute nonmilitary (i.e. civilian) personnel, more readily associated with IPOs.

Secondly, and even more importantly, unlike MMsNCs, members of FPUs sign a letter of undertaking upon being assigned to a UN mission which is identical to the declaration signed by IPOs and by other UN experts on mission. ${ }^{40}$ Significantly, they inter alia declare ${ }^{41}$ to comply with the 'Regulations Governing the Status, Basic Rights and Duties of Officials other than Secretariat Officials, and Experts on Mission' ${ }^{42}$ These facts in turn suggest that, in terms of their status, FPU officers should be assimilated to IPOs and to other UN experts on mission.

The relevant implications of these features (specifically in relation to criminal accountability) and the status and criminal accountability of FPU personnel in general will be explored in the next sections.

\section{The Initial Status and Criminal Accountability of FPU Officers}

\section{Background: Status and Criminal Accountability of Related Personnel Categories}

The introduction of the first formed police units was not preceded by nor did it immediately lead to amendments of the relevant legal texts. As a consequence, applicable legal instruments did (and some even today do) not (explicitly) address the status and criminal accountability of FPU officers in particular. We may, however, look at the regulation of these issues in relation to other personnel categories for guidance concerning the initial legal situation.

For reasons explained above, the controversy concerning the status and criminal accountability of FPU officers relates to the question whether, as UN civilian police officers, they should be treated as UN experts on mission, or can or should rather be assimilated to military members of national contingents. It thus appears useful to consider the position of and relevant rules applicable to these two personnel categories in particular as a background, while highlighting also some general issues in relation to the regulation of the status of personnel in UN missions.

<http://www.navedu.navy.mi.th/stg/databasestory/data/laukniyom/workjob/bigcountry-workjob/UN-

Publications/066-un_ciivpol_principles_and_guidelines\%20.pdf $>4-5,16-29,48,53-56$.

On the other hand, the 2016 external UNPOL review complained of the problem of "[m]ilitary control and militarization of United Nations police components” (Johnson 'External Review of the Functions, Structure and Capacity of the UN Police Division', para. 64, see also ibid., para. 63), but it is unclear if this criticism also relates to FPU/UNPOL mandates or only to the means at their disposal and the ways they are deployed.

39 'Guidelines on Police Operations in United Nations Peacekeeping Operations and Special Political Missions' paras. 20-21 and 'Policy on Formed Police Units in United Nations Peacekeeping Operations' 10, paras. 8 and 46. Even in the DPKO, the overall responsibility over civilian police activities is vested with a separate unit, the United Nations Police Division (part of the Office of Rule of Law and Security Institutions, created in 2007). See $<$ http://www.un.org/en/peacekeeping/sites/police/division.shtml>;

$<$ http://www.un.org/en/peacekeeping/sites/police/documents/unpol_visual_identifier_guidelines.pdf> 12.

${ }^{40}$ See 2006 'Guidelines for Formed Police Units on Assignment with Peace Operations' Annex 3. Compare to DPKO, Police Division, 'Guidelines for United Nations Police Officers on Assignment with Peacekeeping Operations’ (29 June 2007) UN Doc DPKO/PD/2006/00135 Annex 3.

${ }^{41} 2006$ 'Guidelines for Formed Police Units on Assignment with Peace Operations’ Annex 3, para. 2.

${ }^{42}$ UNSG 'Secretary-General's Bulletin (18 June 2002) Regulations Governing the Status, Basic Rights and Duties of Officials other than Secretariat Officials, and Experts on Mission’ [2002] UN Doc ST/SGB/2002/9. 
UN peacekeeping operations are as a rule stationed in the host State under a status of forces agreement (SOFA) concluded between that State and the UN. ${ }^{43}$ Building on extensive practice, the UNGA adopted a model SOFA in $1990^{44}$ containing the rules commonly contained in existing SOFAs. Subsequent status agreements are modelled after this instrument, although deviations from model provisions do occur.

SOFAs explicitly lay down rules concerning inter alia the status of and facilities for the operation and regulate the legal status, privileges and immunities of the following personnel: high ranking UN personnel (including the Special Representative of the SecretaryGeneral, the head of military component and the head of police component), UN civilian staff, experts on mission (including e.g. military observers and CIVPOL/UNPOL), MMsNCs and locally recruited personnel. ${ }^{45}$ Members of FPUs (not yet utilized at the time when that instrument was drafted) are not as such mentioned in the Model SOFA, and the other personnel categories dealt with therein are not defined. However, the instrument does contain rules of importance for this study.

In accordance with the Model SOFA ${ }^{46}$ and provisions modelled after it, UN civilian police enjoy immunities pertaining to experts on mission as provided for in Article VI of the Convention on the Privileges and Immunities of the United Nations. ${ }^{47}$ Most importantly, the CPIUN grants experts on mission immunity for official conduct. ${ }^{48}$ However, as specified in SOFAs, most personnel other than MMsNCs (thus also experts on mission including UN civilian police) may be subject to investigations by the host Government and UN authorities and to local jurisdiction (in the host State) for crimes and misconduct not related to their official duties. Additionally, subject to waiver by the Secretary-General, they may even be tried in the host State in relation to their official conduct. ${ }^{49}$

As for MMsNCs, the Model SOFA specifies that they "shall have the privileges and immunities specifically provided for" therein. ${ }^{50}$ First, it grants such individuals - like all other participants of the operations - immunity for official conduct. ${ }^{51}$ However, it also contains a unique rule in relation to this personnel category: MMsNCs are placed under "the exclusive jurisdiction of their respective participating States in respect of any criminal offences which

\footnotetext{
${ }^{43}$ In the exceptional cases where it has not been possible to conclude a SOFA prior to deployment, the resolution setting up the operation commonly states that the Model SOFA will provisionally apply until the conclusion of an actual SOFA. See e.g. Oswald and Bates, 'Privileges and Immunities of United Nations Police' 383 and Oswald, Durham and Bates, Documents on the Law of UN Peace Operations 34. In addition, according to a legal opinion prepared by the UN's Office of Legal Affairs (hereinafter OLA),
}

[i]f no status-of-forces agreement has been concluded and the model status-of-forces agreement has not been made applicable by the Security Council resolution authorizing the operation, then the status of civilian police officers remains governed by the Convention [on the Privileges and Immunities of the United Nations].

('Letter to the Acting Chair of the Special Committee on Peacekeeping Operations, United Nations, regarding immunities of civilian police and military personnel’ 2004 UNJYB 324.)

${ }^{44}$ Model SOFA.

${ }^{45}$ Ibid., paras. 24-28.

${ }^{46}$ Ibid., para. 26.

${ }^{47}$ Convention on the Privileges and Immunities of the United Nations (adopted 13 February 1946, entered into force 17 September 1946) 1 UNTS 15 (hereinafter CPIUN).

${ }^{48}$ Ibid. Art. VI, Sect. 22(b). See also para. 46 Model SOFA. In addition, the CPIUN (Art. VI, Sect. 22(a)) grants experts immunity from personal arrest and detention. See also para. 42 Model SOFA on rules concerning taking into custody.

${ }^{49}$ Paras. 42-45 and 47(a) Model SOFA.

${ }^{50}$ Ibid., para. 27.

${ }^{51}$ Ibid., para. 46. 
may be committed by them" in the host State. ${ }^{52}$ Unlike UN civilian police, they may thus under no circumstances be subjected to host State criminal jurisdiction for such conduct.

A different type of agreements, memoranda of understanding, constitute an additional potential source of relevant rules. Such agreements are concluded between the UN and the contributing State, regulating the contribution by an individual member State of personnel and equipment to a specific UN operation. Like SOFAs, MOUs are drafted based on a model instrument. This model instrument underwent frequent changes in the past decades. ${ }^{53}$

As they only deal with the contribution of contingents (rather than individually seconded personnel such as IPOs), within UNPOL, MOUs may only be of relevance for FPU officers. However, prior to 2007, the Model MOU did not specifically mention this category and even thereafter it was long silent on the criminal accountability of members of FPUs. ${ }^{54}$

On the other hand, such agreements have become central to discussing the criminal accountability of MMsNCs. MOUs following the current model agreement regulate inter alia issues of (discipline and) criminal jurisdiction. Most significantly, they confirm the SOFA arrangements on exclusive TCC jurisdiction, specifically over military and certain civilian members of the national contingent "while they are assigned to the military component" of the given operation. ${ }^{55}$

However, it is more important at this point that from 1997 to 2007 (thus also in the first years of the existence of FPUs), the model agreement (and actual agreements based on the model instrument) did not contain such provisions. ${ }^{56}$ Accordingly, in this period, MOUs did not even affect the criminal accountability of MMsNCs or other peacekeeping personnel.

\footnotetext{
52 Ibid., para. 47(b).

53 Its current version is reproduced as 'Memorandum of understanding between the United Nations and [participating State] contributing resources to [the United Nations Peacekeeping Operation]' in UNGA 'Manual on Policies and Procedures Concerning the Reimbursement and Control of Contingent-Owned Equipment of Troop/Police Contributors Participating in Peacekeeping Missions (COE Manual)' (20 January 2015) UN Doc A/C.5/69/18 185 (hereinafter Model MOU (2014)). It should be noted that the present article contains references to various (previous) versions of this document. The year denoting a specific version will be specified only if the provision discussed is unique to that version or if this information is otherwise relevant.)

${ }^{54}$ For the version reflecting the 2007 amendments, see 'Memorandum of understanding between the United Nations and [participating State] contributing resources to [the United Nations Peacekeeping Operation]' in UNGA 'Manual on Policies and Procedures Concerning the Reimbursement and Control of Contingent-Owned Equipment of Troop/Police Contributors Participating in Peacekeeping Missions (COE Manual)' (29 January 2009) UN Doc A/C.5/63/18 161 (hereinafter Model MOU (2007)).

${ }^{55}$ Art 7.22 Model MOU (2014). This provision is identical to Art. 7.22 Model MOU (2007).

56 In 2007, the Model MOU underwent substantive amendments in an attempt to ensure the criminal accountability of MMsNCs. On these amendments see e.g. Deen-Racsmány, 'The Amended UN Model Memorandum of Understanding' 321. See also ibid. 329-331 on the amendments between 1991 and 1997. It may, however, be noted that the first version of this instrument (UNGA 'Report of the Secretary-General: Comprehensive Review of the Whole Question of Peace-keeping Operations in All Their Aspects: Model Agreement between the UN and Member States Contributing Personnel and Equipment to UN Peace-keeping Operations' (23 May 1991) UN Doc A/46/185 Annex, paras. 5 and 24-25) indirectly recognized the exclusive jurisdiction of TCCs over MMsNCs by confirming the privileges and immunities of (military and civilian) personnel provided by the TCC and jurisdictional arrangements as specified in the SOFA. However, this provision (or any other regulation of criminal accountability) did not (re)appear in the newly drafted 1996 model agreement (UNGA 'Note by the Secretary-General: Administrative and Budgetary Aspects of the Financing of the United Nations Peacekeeping Operations: Financing of the United Nations Peacekeeping Operations: Reform of the Procedures for Determining Reimbursement to Member States for Contingent-owned Equipment' (9 July 1996) UN Doc A/50/995 Annex ('Contribution Agreement between the United Nations and [Participating State] Contributing Resources to [the United Nations Peace-keeping Operation]')), nor in its 1997 version (UNGA 'Note by the Secretary-General: Administrative and Budgetary Aspects of the Financing of the United Nations Peacekeeping Operations: Financing of the United Nations Peacekeeping Operations: Reform of the Procedures for Determining Reimbursement to Member States for Contingent-owned Equipment' (27 August 1997) UN Doc A/51/967 Annex ('Model Memorandum of Understanding between the United Nations and [Participating State] Contributing Resources to [the United Nations Peacekeeping Operation]’) (hereinafter Model MOU (1997)).
} 
In the absence of relevant rules in MOUs or elsewhere, SOFA exclusive criminal jurisdiction arrangements prevailed: the UN and the host State were at no times entitled to subject MMsNCs to disciplinary or criminal proceedings. From 2003, this idea was also confirmed in the 'Directives for Disciplinary Matters Involving Military Members of National Contingents'. ${ }^{57}$ The sole relevant competence of the UN recognized by these Directives is an administrative sanction: repatriation. ${ }^{58}$

In turn, in relation to UN civilian police, the UN's disciplinary authority and related procedures have - since 2003 - been regulated in the 'Directives for Disciplinary Matters Involving Civilian Police Officers and Military Observers'. In contrast to the 'Directives for Disciplinary Matters Involving Military Members of National Contingents' these directives, applicable to certain categories of experts on mission whose status as experts on mission is explicitly recognized therein, ${ }^{59}$ confirms the authority of the host State to conduct criminal proceedings ${ }^{60}$ and of the UN to investigate the conduct of and impose disciplinary measures over such personnel ${ }^{61}$ in addition to the possibility of national disciplinary proceedings. ${ }^{62}$

The Organization's disciplinary authority over UN civilian police is consistent with the undertaking made by such personnel ${ }^{63}$ and the fact that they declare to be bound by the 'Regulations Governing the Status, Basic Rights and Duties of Officials other than Secretariat Officials, and Experts on Mission'. ${ }^{64}$ Significantly, flowing from this status and in accordance with these regulations, experts on mission (unlike MMsNCs) are directly accountable to the $\mathrm{UN}$ in relation to the exercise of their functions. ${ }^{65}$

We can thus conclude that there were significant differences between the regulation of criminal and disciplinary authority over MMsNCs on the one hand and civilian police officers (experts on mission) on the other in the examined period.

\section{Implications for the Status and Criminal Accountability of Members of FPUs}

It should be recalled that neither the Model SOFA, nor the version of the Model MOU in use at the time of the introduction of FPUs (1999) explicitly mention FPU officers. Following the UN terminology prevailing at the time, the Model SOFA, provides in general terms merely that "UN civilian police" participating in the operation shall have the status of experts on mission for the UN. ${ }^{66}$ Whereas in actual SOFAs this model provision is regularly expanded to cover additional categories of experts on mission, initially SOFAs under which FPUs were deployed did not literally refer to FPUs (or to IPOs). ${ }^{67}$

\footnotetext{
${ }^{57}$ UN Doc DPKO/MD/03/00993 (2003), paras. 8, 28.

${ }^{58}$ Ibid., paras. 16 and 24.

59 'Directives for Disciplinary Matters Involving Civilian Police Officers and Military Observers', para. 8. See however note 74, infra, on the exclusion of FPU officers.

${ }^{60}$ Ibid., paras. 8 and 28.

${ }^{61}$ Ibid., paras. 11-14 (see also paras. 15-22 on Board of Inquiry proceedings) and para. 23, respectively. It may be noted that the UN does not have the authority or capacity to exercise criminal jurisdiction over (any of) its personnel.

${ }^{62}$ Ibid., para. 24.

${ }^{63}$ See note 40, supra and accompanying text.

${ }^{64}$ UNSG 'Secretary-General's Bulletin (18 June 2002) Regulations Governing the Status, Basic Rights and Duties of Officials other than Secretariat Officials, and Experts on Mission'.

${ }^{65}$ Ibid., Regulation 3.

${ }^{66}$ Para. 26 Model SOFA. On the use of this term see note 14, supra.

${ }^{67}$ Of the operations with FPUs (see list at the UN Police website on FPUs), for instance the following SOFAs do not refer to FPU officers: Agreement between the United Nations and the Government of the Republic of Côte d'Ivoire regarding the status of the United Nations Operation in Côte d'Ivoire (Abidjan, 29 June 2004) 2268 UNTS 40393 161, para. 28; Status of Forces Agreement between the United Nations and the Government of the Republic of South Sudan (with supplemental arrangement) (Juba, 8 August 2011) UNTS 48873 $<$ http://unmiss.unmissions.org/LinkClick.aspx?fileticket=gpHXyf3LQ0k\%3D\&tabid=5100\&language=ar-JO>, para. 28; Agreement between Liberia and the United Nations concerning the status of the United Nations
} 
Yet, there is no doubt that FPU officers are and were seen as UN (civilian) police. Accordingly, while not specifically stated so, in the absence of distinctions in applicable SOFA provisions and of other relevant norms which could affect the status of FPU officers in particular, a literal interpretation of applicable rules leads to the conclusion that FPU officers were too meant to be treated as experts on mission even under such (earlier) SOFAs. In this sense, the initial lack of specific references may be taken to evidence that it was apparently not considered necessary to deviate from existing norms following the introduction of FPUs; FPU officers could simply be accommodated in the category of civilian police. Hence, all SOFA rules applicable to civilian police should also apply to them. This reading is confirmed by recent SOFAs which refer in relevant provisions to "UN civilian police, including members of formed police units”. ${ }^{6}$

Consistently with this position, the suggested parallel with MMsNCs is denied - at least in legal terms - by a closer look at the relevant SOFA provisions on MMsNCs. The model provision on criminal jurisdiction over such personnel (subjecting them to exclusive TCC jurisdiction) contains a crucial phrase, referring specifically to "[m]ilitary members of the military component”. ${ }^{69}$ As FPU officers are not part of the military component, ${ }^{70}$ this provision cannot be read as applicable to such personnel.

In turn, MOUs concluded at the time of the introduction of FPUs had no impact on the status and accountability of FPU officers. ${ }^{71}$ In addition, while MOUs modelled after the 2007 version do address the question of criminal jurisdiction in relation to MMsNCs, the applicability of the relevant provision to FPUs appears to be negated by the qualification "while they are assigned to the military component" of the given operation. ${ }^{72}$

The conclusion that FPU officers are to be treated as UN civilian police, hence experts on mission, thus appears unchallenged by these instruments. Consequently, and in line with the undertakings and declaration made by FPUs (identical to version for IPOs) ${ }^{73}$, it would appear that FPU officers too may be subject, next to host State criminal jurisdiction, to the disciplinary authority of the UN.

Somewhat surprisingly in light of this seemingly neat legal regime, the 2003 'Directives for Disciplinary Matters Involving Civilian Police Officers and Military Observers' explicitly excluded FPU officers from the scope of its coverage, placing responsibility for disciplinary action in respect of them with the national unit commanders. ${ }^{74}$

Mission in Liberia (Monrovia, 6 November 2003) 2300 UNTS 41006 127, para. 28; Agreement between the United Nations and the Government of Haiti concerning the status of the United Nations Operation in Haiti (Port-au-Prince, 9 July 2004) 2271 UNTS 40460 235, para. 28.

${ }^{68}$ See e.g. Status of Forces Agreement between the United Nations and the Government of the Central African Republic relating to the United Nations Multidimensional Integrated Stabilization Mission in the Central African Republic (Bangui, 2 September 2014) UNTS 52177, para. 29 and Status of Forces Agreement between the United Nations and the Government of the Republic of Mali concerning the United Nations Multidimensional Integrated Stabilization Mission in Mali (Bamako, 1 July 2013) UNTS 51015, para 28.

${ }^{69}$ Para. 47(b) Model SOFA.

${ }^{70}$ See text accompanying note 39 , supra.

${ }^{71}$ It may be noted that there is some ambiguity as to which model was in use from 1999 (the deployment of the first FPUs) to 2007. See Deen-Racsmány, 'The Amended UN Model Memorandum of Understanding' 330, n. 44. However, this question is immaterial as none of the claimed versions contained relevant provisions. See note 56, supra and accompanying text.

${ }^{72}$ Art. 7.22 Model MOU (2007). See text accompanying note 39, supra.

73 See notes 40-41, supra and accompanying text.

74 'Directives for Disciplinary Matters Involving Civilian Police Officers and Military Observers', original version (prior to 2005 amendments) <https://cdu.unlb.org/Portals/0/PdfFiles/PolicyDocG.pdf> n. 1, stating that

[t]hese Directives shall not be applicable to members of national formed police units. Responsibility for disciplinary action in these units rests with the commanders of the national units, who must keep the Head of Mission fully informed in all disciplinary matters. 
In terms of their disciplinary and criminal accountability, FPU officers were hereby explicitly divorced from IPOs and other experts on mission participating in UN peacekeeping operations, and placed rather on a footing similar to MMsNCs (although they were not explicitly covered by the 'Directives for Disciplinary Matters Involving Military Members of National Contingents' either ${ }^{75}$ ). The 'Directives for Disciplinary Matters Involving Civilian Police Officers and Military Observers' thus clearly blurred the initially clear legal picture, demonstrating that the position of FPU officers is less than unambiguous. Opposing views concerning this issue and relevant developments - leading to the adoption of the Directives and subsequent to those - will be explored in the next section.

\section{UN (Secretariat) versus PCCs (Members of the C-34): Gradual Clarification of the Position of FPU Officers}

As evidenced by the reports of the Special Committee on Peacekeeping Operations, the legal position and criminal accountability of FPU officers (and indeed of UN civilian police as a whole) have been contentious ever since such units were first deployed. A protracted dispute between the C-34 and the UN Secretariat apparently triggered a gradual clarification of these issues, through amendments of rules if necessary, contributing to consensus.

A detailed study of this process presented below can thus enhance our understanding of the current status quo and of the likelihood of future change on these matters. In addition, a review of relevant developments may provide valuable insights concerning the attitude of troop and police contributors towards criminal accountability in UN peacekeeping operations in general.

\section{1999-2005: Opposing Positions Crystallize}

It is a widely recognized that UN peacekeeping entered a new phase following the end of the Cold War. It is, however, perhaps less well known that this change also had a significant impact on the tasks of UN civilian police, leading to the introduction of FPUs with executive mandates. ${ }^{76}$ The Special Committee followed these developments with concern, alerting already in 1999 that "in conducting a peacekeeping operation, care should be taken to ensure that, consistent with the mandate, police and military tasks should be clearly differentiated." In subsequent years, members of the Committee repeatedly called for the development of guidelines on general principles concerning the role of CIVPOL, stressing the need to distinguish between military and police action on each occasion. ${ }^{78}$ In 2000 , the SecretaryGeneral even referred in this context to the need to reach a political consensus, demonstrating the delicacy of the then prevailing situation. ${ }^{79}$ In addition, the Committee warned that "potentially dangerous situations [were] likely to be encountered by [CIVPOL] personnel in

See, however, Section IV.2., infra, on relevant amendments.

${ }^{75}$ On this issue, see note 89 , infra and accompanying text.

${ }^{76}$ See text accompanying notes 17-29, supra.

${ }^{77}$ UNGA 'Report of the Special Committee on Peacekeeping Operations: Comprehensive review of the whole question of peacekeeping operations in all their aspects’ (23 June 1999) UN Doc A/54/87, para. 100.

${ }^{78}$ UNGA 'Report of the Special Committee on Peacekeeping Operations: Comprehensive review of the whole question of peacekeeping operations in all their aspects' (20 March 2000) UN Doc A/54/839, para. 34 (see also ibid., paras. 131-132); UNGA 'Report of the Special Committee on Peacekeeping Operations: Comprehensive review of the whole question of peacekeeping operations in all their aspects' (4 December 2000) UN Doc A/C.4/55/6, para 25.

${ }^{79}$ UNGA 'Report of the Special Committee on Peacekeeping Operations: Comprehensive review of the whole question of peacekeeping operations in all their aspects’ (20 March 2000), para. 12. 
the performance of their duties", emphasizing the need to adjust rules of engagement for CIVPOL - "mandated and required to carry arms" - to this reality. ${ }^{80}$ These concerns were undoubtedly at least in part inspired by the invention of FPUs and the broadened, more robust mandates increasingly assigned specifically to such police personnel.

In 2000, the DPKO prepared a set of principles and guidelines for CIVPOL ${ }^{81}$ which were welcomed by the C-34. However, this document - confirming the possibility that force may be used by CIVPOL personnel and that they may be granted executive powers and enforcement mandates ${ }^{82}$ - apparently invoked more concerns then it removed. As stated in the 2002 report of the $\mathrm{C}-34$,

[m]any delegations sought clarification as to the legal status of civilian police officers serving with the United Nations, considering them part of a national contribution rather than individual civilian specialists, and noted that civilian police should be repatriated for investigation [hence not subjected to host State jurisdiction] in cases of alleged gross misconduct. ${ }^{83}$

The requested information was provided by the Under-Secretary-General. ${ }^{84}$

However, some delegations apparently found the situation as explicated unsatisfactory; they called for clarification (again) in 2003. ${ }^{85}$ This time, the Committee was more specific and resolute:

The Special Committee stresse[d] that when civilian police and corrections personnel are assigned executive tasks, in which they directly implement law and order functions, they may be required to use enforcement measures in accordance with their mandates and the rules of engagement. In this regard, the Committee request[ed] that the Secretariat consider assigning such personnel privileges and immunities equivalent to those of armed military personnel. ${ }^{86}$

In light of this request, it may come as no surprise that the 'Directives for Disciplinary Matters Involving Civilian Police Officers and Military Observers' issued by the DPKO in $2003^{87}$ went a long way to accommodate the position of the C-34 in relation to FPU officers, excluding such personnel from the scope of the Directives. ${ }^{88}$ While the author has not been able to identify relevant practice, there are indications that instead of this instrument, the 'Directives for Disciplinary Matters Involving Military Members of National Contingents'

\footnotetext{
${ }^{80}$ Ibid., para. 139.

${ }^{81}$ DPKO, United Nations Civilian Police Principles and Guidelines.

${ }^{82}$ Ibid. 10, 23, 48-49.

${ }^{83}$ UNGA 'Report of the Special Committee on Peacekeeping Operations: Comprehensive review of the whole question of peacekeeping operations in all their aspects' (11March 2002) UN Doc A/56/863, para. 43, emphasis added. It should be stressed that reference was made here to civilian police, not to FPU officers in particular.

${ }^{84}$ Ibid., Annex II, para. 2.

${ }^{85}$ UNGA 'Report of the Special Committee on Peacekeeping Operations: Comprehensive review of the whole question of peacekeeping operations in all their aspects’ (28 March 2003) UN Doc A/57/767, para. 27.

${ }^{86}$ Ibid., para. 112. Emphases added.

${ }^{87}$ As stated in the Directives (Art. I.1) their aim is "to establish United Nations procedures to be followed for alleged breaches of conduct in the mission area” by such personnel. Accordingly, they inter alia build and elaborate on SOFA provisions on criminal jurisdiction and specify the UN's administrative and disciplinary authority and related proceedings in relation to specific categories of personnel.

${ }^{88}$ On the relevant provisions of the Directives and specifically on the exclusion of FPU officers, see text accompanying notes 60-62 and 74-75, supra, respectively.
} 
(building on the principle of exclusive TCC criminal jurisdiction) may have been applied to members of FPUs in a subsequent brief period. ${ }^{89}$

Yet, the Special Committee was still not satisfied. During its 2004 session, its Acting Chair requested "written information regarding immunities of civilian police and military personnel" from the Secretariat. ${ }^{90}$ The Office of Legal Affairs responded - without explicitly noting the existence of two distinct categories of civilian police (IPOs and FPUs officers) stressing that such personnel have the status of experts on mission for the UN in the sense of Article VI CPIUN, even if no SOFA has been concluded. Accordingly, such personnel are granted functional immunity. On the other hand, the opinion continued,

[i]t is ... possible and consistent with the [CPIUN and the Model SOFA], that a United Nations civilian police officer be prosecuted in the host State for a criminal act, even if committed in the course of performing his or her functions, where immunity for that act would impede the course of justice and that immunity can properly be waived. ${ }^{91}$

In contrast, in relation to MMsNCs the OLA concluded, citing inter alia paragraph 47(b) of the Model SOFA ${ }^{92}$, that they are subject to the exclusive criminal jurisdiction of the TCC, hence they do not fall under the criminal jurisdiction of the host State. The OLA explained this fact (and in turn the difference between the rules applicable to military and police personnel) by noting that

[t]his immunity from criminal jurisdiction in a host State can be justified, inter alia, by the fact that military personnel, as a rule, are subject to their own distinct military judicial system, including for acts committed by them outside their own country. ${ }^{93}$

The OLA thus clearly did not support any parallel between the status and immunities of MMsNCs and FPUs, and it even ignored the argument related to possible similarities in terms of their tasks. Instead, it focused on the existence of TCC jurisdiction over MMsNCs, not addressing this issue in relation to UN civilian police and FPUs in particular. ${ }^{94}$

This legal opinion was presented to the C-34 at the same session. ${ }^{95}$ Some members of the Committee apparently found the position adopted by the OLA unsatisfactory and

\footnotetext{
${ }^{89}$ An opinion prepared by the OLA in 2005 stated that "it certainly would not be appropriate to apply, or to continue to apply, to members of FPUs the ['Directives for Disciplinary Matters Involving Military Members of National Contingents']”. ('Note to the Under-Secretary-General for the Department of Peacekeeping Operations, concerning Formed Police Units', UNJYB $\quad$ Special $<$ http://legal.un.org/docs/?path=../unjuridicalyearbook/pdfs/english/by_chapter/chpVI/legal_opinions/2005.pdf\& lang $=\mathrm{E}>2$, emphasis added, original italics removed. It should however be stressed that nothing in these Directives suggests that members of FPU officers are covered by its provisions.

${ }^{90}$ See OLA, 'Letter to the Acting Chair of the Special Committee on Peacekeeping Operations, United Nations, regarding immunities of civilian police and military personnel' 323.

${ }^{91}$ Ibid. 324.

92 See text accompanying note 52, supra.

${ }^{93}$ OLA, 'Letter to the Acting Chair of the Special Committee on Peacekeeping Operations, United Nations, regarding immunities of civilian police and military personnel' 325.

${ }^{94}$ It may be noted that police officers too are not uncommonly subject to a distinct (police/gendarmerie) code of discipline, weakening the distinction made by the OLA. On this issue and related problems see text accompanying notes 158-162, infra.

95 This impression is gained from statements reproduced in UNGA 'Report of the Special Committee on Peacekeeping Operations and its Working Group at the 2004 substantive session’ (26 March 2004) UN Doc A/58/19, paras. 24 and 134.
} 
reiterated their concern that civilian police and corrections personnel may need to undertake enforcement measures. They called for "an adaptation of the current rules governing their legal status" and - again - for equating civilian police to MMsNCs in terms of their privileges and immunities. ${ }^{96}$ In addition, they pressed in strong words for the UN Secretariat to convene a meeting with member States (as proposed by the Secretariat in 2003) to discuss the status of such personnel. ${ }^{97}$

At the Committee's next session, in 2005, the same concerns and requests regarding (an adaptation of) the legal status and privileges and immunities of civilian police were repeated, now with specific reference to FPU officers as well. ${ }^{98}$ However, on this occasion, the Special Committee went further than previously,

call[ing] upon the Secretariat to submit a report on the legal status of civilian police personnel who are assigned executive tasks, including operational recommendations to address the concerns of the Special Committee in an appropriate manner, taking into account contributions by Member States and the practice of relevant regional organizations. ${ }^{99}$

\section{2005-2007: UN's Position Is Crystal Clear}

The process called for by the C-34 was interrupted by unexpected developments: the revelation of large scale sexual exploitation and abuse by UN peacekeepers. Following the presentation of the Zeid report ${ }^{100}$ on this issue in 2005 which contained extensive recommendations addressed to the UN and member States to tackle this problem, all relevant UN bodies and committees concentrated on eliminating SEA in 2005-2007. The C-34 focused inter alia on amending the UN Model MOU. ${ }^{101}$ Yet, even in this period there were some developments relevant for this study, possibly also triggered by these events.

In September 2005, the OLA received two distinct requests for clarification of the status of members of FPUs. ${ }^{102}$ The first concerned the applicability of the 'Directives for Disciplinary Matters Involving Civilian Police Officers and Military Observers' to members of FPUs. The other sought inter alia to have the status of members of FPUs as experts on mission for the UN confirmed and inquired about the disciplinary regime applicable to them.

The response of the OLA was categorical, stating in unequivocal terms and with specific reference to members of FPUs that they are experts on mission for the UN within the meaning of Article VI of the CPIUN and as specified in paragraph 26 of the Model SOFA. ${ }^{103}$ The Office added:

This continues to be the case, notwithstanding that the members of an FPU may be provided to the United Nations pursuant to a memorandum of understanding or agreement concluded by the Organization with the State that

\footnotetext{
${ }^{96}$ Ibid., para. 134. See also ibid., para. 24.

${ }^{97}$ Ibid., para. 134.

${ }^{98}$ UNGA 'Report of the Special Committee on Peacekeeping Operations and its Working Group at the 2005 substantive session’ (1 March 2005) UN Doc A/59/19, para. 81.

${ }^{99}$ Ibid., para. 82.

${ }^{100}$ Prince Zeid R.Z. Al-Hussein, ‘A Comprehensive Strategy to Eliminate Future Sexual Exploitation and Abuse in United Nations Peacekeeping Operations’ (24 March 2005) UN Doc A/59/710 (hereinafter Zeid Report).

101 See UNGA 'Report of the Special Committee on Peacekeeping Operations and its Working Group' (2007) UN Doc A/61/19/Rev.1 summarizing its work in 2006-2007.

102 See OLA, 'Note to the Under-Secretary-General for the Department of Peacekeeping Operations, concerning Formed Police Units' 1. The senders of these letters are not made public.

103 See text accompanying note 46.
} 
contributes them, notwithstanding that they may not individually sign any agreement, contract or undertaking with the Organization and notwithstanding that they may not directly receive any remuneration from the United Nations. As the International Court of Justice has observed, an expert on mission may or may not have a contract, and may or may not be remunerated. The essence of the matter lies not in their administrative position, but in the fact that they have been entrusted with, or are performing, a mission for the United Nations. Members of FPUs undoubtedly fall within this definition. ${ }^{104}$

The OLA even explained that the fact that the DPKO has sought waivers of such immunities (specified in Article VI of the CPIUN) in relation to members of FPUs and the OLA has executed such waivers on behalf of the Secretary-General indicates that this position has been applied in practice on several occasions. ${ }^{105}$ As noted in the opinion, this position was communicated to the Special Committee on Peacekeeping Operations earlier in 2005. ${ }^{106}$

Turning to the issue of disciplinary regime, the OLA stated that considering the contents of a September 2005 Code Cable,

it certainly would not be appropriate to apply, or to continue to apply, to members of FPUs the Directives for Disciplinary Matters Involving Military members of National Contingents [...]. In particular, members of FPUs are not, as supposed by those Directives, subject to the exclusive jurisdiction of the State contributing them in respect of any criminal offences that they might commit in the territory of the State hosting a peacekeeping mission. Rather, as is clear from what is said above, they are subject to the criminal jurisdiction of the host State:

- with regard to acts done by them otherwise than in the course of the performance of their missions; and

- with regard to acts done by them in the course of the performance of their missions, if the Secretary-General decides to waive the immunity from legal process that they enjoy in respect of such acts. ${ }^{107}$

It was thus (repeatedly) made clear that the UN was of the opinion that PCCs did not have exclusive criminal jurisdiction over members of FPUs, nor was it - in the face of mounting pressure by troop and police contributors - prepared to grant FPU officers such protection. Rather, the OLA opinion even categorically stated that "it would be fully appropriate to amend [the 'Directives for Disciplinary Matters Involving Civilian Police Officers and Military Observers'] and to make them applicable to members of FPUs [...]”. ${ }^{108}$

This position was implemented promptly. Four days after the issuance of this OLA opinion, Code Cable 2697 of 7 October 2005 rendered the 'Directives for Disciplinary Matters Involving Civilian Police Officers and Military Observers' applicable to FPU officers in all UN peacekeeping operations. ${ }^{109}$ The Code Cable amended the first sentence of the footnote attached to the provision concerning its scope, thus explicitly providing for the

\footnotetext{
104 OLA, 'Note to the Under-Secretary-General for the Department of Peacekeeping Operations, concerning Formed Police Units’ 2.

105 Ibid. 2.

106 Ibid. 2.

107 Ibid. 2-3. Emphases in original.

108 Ibid. 2.

109 See 2006 ‘Guidelines for Formed Police Units on Assignment with Peace Operations’ 7, n. 3.
} 
application of the Directives to members FPUs. The second sentence of the same footnote stating inter alia that "[r]esponsibility for disciplinary action in these units rests with the commanders of the national units" was left unaltered. ${ }^{110}$

In 2006, the DPKO adopted two documents pressed for by the C-34 ${ }^{111}$, the 'Policy on Functions and Organization of Formed Police Units in United Nations Peacekeeping Operations'112 and the 'Guidelines for Formed Police Units on Assignment with Peace Operations' ${ }^{113}$. However, in contrast to the position of the Committee set out in the previous section, both these documents treat FPUs as experts on mission, and attribute the usual consequences (i.e. those pertaining also to IPOs) of this status to them in terms of immunities, the permissibility of host State jurisdiction, and disciplinary matters. ${ }^{114}$

In light of these developments, it barely came as a surprise that the amended Model MOU adopted in $2007^{115}$ does not equate members of FPUs to MMsNCs. While a model provision confirms the TCC's exclusive criminal jurisdiction over "[m]ilitary members and any civilian members subject to national military law of the national contingent provided by the Government", it restricts this right to the duration of the assignment of such personnel "to the military component". ${ }^{116}$ Considering that FPUs form part of the police rather than of the military component of UN operations, ${ }^{117}$ this provision clearly does not apply to them. ${ }^{118}$

110 Art. II.2 'Directives for Disciplinary Matters Involving Civilian Police Officers and Military Observers' (current version), n.1. See also the 2003 version for the original formulation.

111 See UNGA 'Report of the Special Committee on Peacekeeping Operations and its Working Group at the 2006 substantive session’ (20 March 2006) UN Doc A/60/19, para. 102.

112 DPKO, 'Policy on Functions and Organization of Formed Police Units in United Nations Peacekeeping $\begin{array}{llll}\text { Operations' } & (9 & \text { November } & \text { 2006) }\end{array}$ $<$ https://www.un.org/ruleoflaw/files/Policy\%20on\%20the\%20functions\%20and\%20organization\%20of\%20For med\%20Police\%20Units\%20in\%20United\%20Nations\%20Peacekeeping\%20Operations.doc>. This document is an outdated version of the 2010 'Policy on Formed Police Units in United Nations Peacekeeping Operations'.

1132006 'Guidelines for Formed Police Units on Assignment with Peace Operations'.

${ }^{114}$ Ibid. 5, para. 14; 7, n. 3; 9, para. 30; 'Policy on Functions and Organization of Formed Police Units in United Nations Peacekeeping Operations’ 3, para. 4.6.

${ }^{115}$ Model MOU (2007). It may be noted that the C-34 has participated in the amendment process. See 2007 COE Manual containing the Model MOU (2007) 161.

${ }^{116}$ Art. 7.22 Model MOU (2007). See also ibid., Art. 7.23. It may be noted that, in contrast, the provisions of the Model MOU (2007) on standards of conduct ( 7 bis), discipline $(7$ ter), investigations (7 quarter) and accountability (7 sexiens) deal with members of national contingents, without specifically referring to military personnel or to military component.

117 See text accompanying note 39, supra. See to this effect also the Report of the Second Group of Legal Experts (hereinafter GLE2): UNGA 'Report of the Group of Legal Experts on making the standards contained in the Secretary-General's bulletin binding on contingent members and standardizing the norms of conduct so that they are applicable to all categories of peacekeeping personnel' (18 December 2006) UN Doc A/61/645, para. 5 (hereinafter GLE2 Report)

118 This conclusion is additionally confirmed by the fact that various provisions of the Model MOU (2007) do refer to troop/police contributors, clearly intending to cover also FPUs while recognizing the distinction between that group and MMsNCs, whereas Arts. 7.22-7.23 ibid. deal clearly only with military contingents. In addition, it may be noted that the GLE2 even specifically stated in its report that members of FPUs, although contributed similarly to MMsNCs, do not fall under the exclusive jurisdiction of the contributing State. GLE2 Report, para. 5, n. 3.

Similarly, in a parallel project, the Group of Legal Experts mandated to study the criminal accountability of UN officials and experts on mission (hereinafter GLE) noted in relation to FPUs in 2006 that

[t] he members of such units are currently classified as experts on mission and therefore benefit from functional immunity. Should their legal status under governing instruments change so that they are said to fall under the exclusive jurisdiction of their sending State, it is essential that these instruments contain provisions to ensure that the sending State is obliged to extend and enforce its laws over the criminal conduct of those persons. 
Indeed, as indicated by the Secretary-General in his contribution to the amendment process, it was clearly not the intention of the UNGA to extend the coverage of the new provisions to FPU officers. ${ }^{119}$ In this light it even appears unlikely that the new MOU rules, for instance, on discipline and investigations (containing obligations in relation to members of national contingents but without further reference to assignment to the military component) are meant to cover FPU officers. ${ }^{120}$ Accordingly, the 2007 amendments to the Model MOU, and the provisions modelled after the Model MOU (2007) in actual agreements (on standards of conduct, discipline, investigations, exercise of jurisdiction and accountability), do not seem to affect the relevant rights and obligations of member States (PCCs or host) or the UN in relation to FPU officers.

\section{Post 2007: (Reluctant) Acceptance of the Situation by the Special Committee}

Following the adoption of the amended Model MOU in 2007, the C-34 ceased its calls for exclusive PCC criminal jurisdiction over FPU officers or UN (civilian) police in general. In addition, from 2010 the Committee even kept explicitly acknowledging in its annual report "that the role of troops and police, and likewise, the needs of troop-contributing countries and police-contributing countries can also be distinct”. ${ }^{121}$

UNGA 'Report of the Group of Legal Experts on ensuring the accountability of United Nations staff and experts on mission with respect to criminal acts committed in peacekeeping operations' (16 August 2006) UN Doc A/60/980 (hereinafter GLE Report) 9, n. 8, emphasis added.

${ }^{119}$ In a report presenting his amendment proposals (UNGA 'Note by the Secretary-General: Revised draft model memorandum of understanding between the United Nations and [participating State] contributing resources to [the United Nations Peacekeeping Operation]' (3 October 2006) UN Doc A/61/494 3, n.*), the SecretaryGeneral explicitly noted that

[g]iven that the requests of the General Assembly are limited to revisions to the draft model memorandum of understanding between the United Nations and troop-contributing countries only, all references in chapter 9 of the COE Manual relating to the contribution of police personnel should be disregarded for present purposes.

The version of the Model MOU in use at the time according to the Secretary-General (UN Doc A/C.5/60/26 (22 December 2005), based on the Model MOU (1997)), to which his amendment proposals refer, did not regulate criminal jurisdiction or discipline.

The "mandated revisions" referred to by the Secretary-General have their origins in the recommendations of the Special Committee on Peacekeeping Operations (UN Doc A/59/19/Rev.1, Part Two, Chapter II, para. 39, cited by the Secretary-General in his report at 1) which in turn build on the Zeid report. Most significantly, the C-34 cited paragraphs 71 and 77-79 of the latter report, addressing discipline and exercise of criminal jurisdiction in relation to TCCs and MMsNCs only. No parallel recommendations have been presented by Prince Zeid in relation to PCCs and FPU officers. The source of the limitation of the scope of amendments concerning disciplinary action and criminal jurisdiction to TCCs and MMsNCs thus appears to lie in the Zeid report. In endorsing Prince Zeid's recommendations, the C-34 did not (explicitly) object to this restriction. Cf. notes 117-118, supra on relevant statements in the reports of GLE and GLE2.

Somewhat peculiarly, in his report presented on 24 March 2005 (about six months before Code Cable 2697 was issued, see on this development text accompanying note 109, supra) Prince Zeid considered all UN police (at the time CIVPOL) officers without distinction as experts on mission, stating that the 'Directives for Disciplinary Matters Involving Civilian Police Officers and Military Observers’ (2003 version) were applicable to (all) CIVPOL officers. Zeid report, e.g., paras.18, A.14, A.17 A.22.

120 See note 116 , supra.

121 See e.g. UN Docs. A/64/19 (2010), para. 226; A/65/19 (2011), para. 88; A/66/19 (2012), para. 98 and A/68/19 (2014), para. 105. This led the Committee to refer in its reports to “'troop-contributing countries' and 'police-contributing countries' singularly or concurrently, depending on the context." (UNGA 'Report of the Special Committee on Peacekeeping Operations: 2014 Substantive Session’ (2014) UN Doc. A/68/19, para. 105.) 
Yet, it is still not entirely clear whether the Special Committee really acquiesced in the UN's position. Overall, the statements related to FPUs in the Committee's yearly reports appear admittedly to be consistent with the status of FPU officers as experts on mission (and with the provisions of the amended Model MOU (2007) to the extent that those are relevant at all). ${ }^{122}$ Yet, even reports produced after 2007 still contain a few pronouncements which may be seen as indications of the old attitude in the C-34. For instance, the 2011 report notes in relation to all peacekeeping personnel that

[t]he Special Committee stresses that in the case of any violations of standards, appropriate action will be taken within the authority of the Secretary-General, while criminal and disciplinary responsibility in respect of members of national contingents will depend on the national law of the Member State. ${ }^{123}$

As noted above, flowing from the position of FPU officers as experts on mission, the host State may exercise criminal jurisdiction over such individuals and the UN has some (limited) disciplinary powers. ${ }^{124}$ Hence, this statement appears to be inconsistent with relevant legal consequences of the status of members of FPUs. ${ }^{125}$

Although not equally clearly problematic, the position adopted in several reports that the determination of SEA related misconduct, "for military and police personnel, is based on investigations by troop- and police-contributing countries, as stipulated under the revised memorandum of understanding" ${ }^{\prime 126}$ is also somewhat controversial. This position is barely consistent with the fact that the UN and the host State have the right under SOFAs to conduct investigations in relation to accusations against FPU officers. ${ }^{127}$ In addition, as noted above, it appears questionable whether the provisions of the revised model MOU have any relevance for investigations by PCCs. ${ }^{128}$

At any event, relevant UN documents produced after 2007 confirm the status of FPU officers as experts on mission. ${ }^{129}$

122 The most common recent formulations in C-34 reports are limited to reiterations of the principle that "troopand police-contributing countries bear the primary responsibility for maintaining discipline among their contingents deployed in peacekeeping missions”. (UN Docs. A/62/19 (2008), para. 56; A/63/19 (2009), para. 50; A/64/19 (2010), para. 50; A/65/19 (2011), para. 48; A/66/19 (2012), para. 54; UNGA 'Report of the Special Committee on Peacekeeping Operations: 2014 Substantive Session’, para. 60; A/69/19 (2015), para. 62.) Other relevant statements concern calls for member States to provide the UN Secretariat with

information on disciplinary actions taken at the national level with respect to substantiated cases of misconduct by military and police personnel and improve responsiveness in this regard.

UN Doc A/66/19 (2012), para. 58, see also UN Doc A/69/19 (2015), para. 66.

${ }^{123}$ UNGA 'Report of the Special Committee on Peacekeeping Operations: 2011 Substantive Session’ UN Doc A/65/19 (May 2011), para. 49, emphasis added.

124 See text accompanying note 73, supra.

125 Admittedly, the phrase "members of national contingents" may be interpreted to cover only MMsNCs. However, this reading is rendered implausible by the reference in the previous paragraph of the same report to the responsibility of TCCs and PCCs "for maintaining discipline ... among their contingents deployed in peacekeeping missions". UNGA 'Report of the Special Committee on Peacekeeping Operations: 2011 Substantive Session', para. 48, emphasis added.

${ }^{126}$ UNGA 'Report of the Special Committee on Peacekeeping Operations: 2014 Substantive Session’ para. 65.

127 See notes 49 and 61, supra and accompanying text.

128 See text accompanying notes 119-120, supra.

${ }^{129}$ See e.g. UNGA 'Report of the Secretary-General: Criminal accountability of United Nations officials and experts on mission' (11 August 2008) UN Doc A/63/260, para. 65; UNGA 'Report of the Secretary-General: Overview of the financing of the United Nations peacekeeping operations: budget performance for the period from 1 July 2011 to 30 June 2012 and budget for the period from 1 July 2013 to 30 June 2014' (31 January 


\section{2014 Amendments to the Model MOU: It Can't Get Any Clearer!}

The consideration of changes to the Model MOU did not terminate upon the adoption of the amendments inspired by the SEA scandals in 2007. The Working Group on ContingentOwned Equipment continued reviewing the entire system as well as its particular aspects on a regular basis - reporting to the Fifth Committee of the UNGA -, together with the SecretaryGeneral and the Advisory Committee on Administrative and Budgetary Questions. ${ }^{130}$

In addition, at least from the early 2010s, the UN Police division was working specifically on

updating/strengthening the language in the disciplinary directives for UN Police and the Memorandum of Understanding for formed police units with clearer provisions on immunity, the applicable legal process, roles and responsibilities of the UN and police contributing countries, operating procedures on investigations, reporting and handling of evidentiary material. ${ }^{131}$

While the present author has not been able to trace these processes accurately, it is clear that they (presumably together with work conducted by other bodies) have led to significant amendments of the Model MOU. Since 2014, that instrument has two generic models: one for the contribution of military contingents and a separate one for the contribution of FPUs. Even though the generic model for military contingents has undergone some changes, relevant provisions (on jurisdiction, discipline, investigations, etc.) are unaltered. ${ }^{132}$

In contrast, the parallel provisions of the generic model for FPUs contain very different rules than those prescribed for MMsNCs, relevant for the present study. First, Article 7.7 confirms the requirement imposed on members of FPUs to sign the "'Undertaking and Declaration by Experts on Mission', referring to the United Nations standards of conduct $[\ldots]$... ${ }^{133}$

Secondly, while the first two provisions of Article 7 ter on discipline are nearly identical to the rules stated under the same heading in the model for military contingents, there are some minor differences. ${ }^{134}$ In addition, in the FPU version, this section contains two additional brief provisions, one relating to pre-deployment training for the Commander of the FPU and, even more significantly from our perspective, one explicitly subjecting FPU officers "to United Nations procedures for breaches of conduct as set forth in annexes I ['Guidelines for Formed Police Units on Assignment with Peace Operations'] and J ['Directives for Disciplinary Matters Involving Civilian Police Officers and Military Observers’].”135

2013) UN Doc A/67/723, para. 131 and DPKO/DFS, 'Policy on United Nations Police in Peacekeeping Operations and Special Political Missions', para. 22.

130 These are the only actors listed in the COE Manual (2014) 3-6. However, the available documents adopted in recent years by these bodies fall short of explaining the changes related to FPUs to be discussed below.

131 DPKO, UN Police Magazine (9th ed., July 2012 ) 12, $<$ http://www.un.org/en/peacekeeping/publications/unpolmag/unpolmag_09.pdf>.

${ }^{132}$ Art. 7 Model MOU (2014), Generic Model for Military Contingents. See however Art. 7 Septies, containing a novel provision on Environmental compliance and waste management.

${ }^{133}$ Model MOU (2014), Generic Model for Formed Police Units.

134 The only significant (and probably barely accidental) deviation is that while the model for FPUs refers to the duty of the Government to inform the UN "[...] of any matters involving the discipline and good order of members of the unit, including any disciplinary action” (ibid., Art. 7.9, emphasis added), the model for military contingents limits this obligation to "any serious matters" (Art. 7.6 Model MOU (2014), Generic Model for Military Contingents, emphasis added).

135 Arts. 7.10-7.11 Model MOU (2014), Generic Model for FPUs. 
Thirdly, the difference between the corresponding sections of the two generic models on investigations is equally striking. The Model MOU (2007) - similarly to the 2014 generic version for military contingents - severely restricted the pre-existing powers of the UN/Office of Internal Oversight Services (OIOS) to investigate misconduct and crime allegedly committed by members of national contingents, placing the primary responsibility for conducting investigations with the TCC. ${ }^{136}$ These restrictions apparently did not apply to FPUs. ${ }^{137}$ At any event, the 2014 generic version for FPUs confirms in the first place the competence of the UN/OIOS to investigate, while also recognizing the rights of the PCC and even of the host State to conduct their own investigations. ${ }^{138}$ Significantly, the FPU version even attempts to eliminate a problem in this context, commonly faced by the UN in relation to MMsNCs when intending to exercise its (in that context secondary) right to conduct administrative investigations, by stating that

[t]he Government undertakes to ensure that no individual against whom there are allegations of any forms of misconduct is repatriated before the conclusion of the investigation by the United Nations and a determination is made regarding the appropriate action to be taken in the matter. ${ }^{139}$

Fourthly, the contributing State's self-assumed duty to cooperate is formulated more broadly in the FPU version than in the generic model for military contingents. Most significantly, in the FPU version (in contrast to the one for military contingents), the obligation to cooperate is not (explicitly) made subject to applicable national laws (including military laws). ${ }^{140}$

Fifthly, the most pertinent dissimilarity can be observed in relation to Article 7 quinquiens on exercise of jurisdiction. The generic model for military contingents unequivocally confirms the exclusive jurisdiction of TCCs laid down in SOFAs (while imposing an obligation on the TCC to exercise its criminal or disciplinary jurisdiction). ${ }^{141}$ In contrast, the FPU version confirms the status of FPU officers as civilian police hence as experts on mission for the UN and the resulting immunity ratione materiae, while noting that they may be subject to host State criminal jurisdiction if such immunities are waived or declared inapplicable by the Secretary-General. It even obliges the PCC in the latter case to cooperate with the host State. ${ }^{142}$ In addition, the document seems to build on the idea that the host State has a primary right to exercise criminal jurisdiction. However, if the host State does

\footnotetext{
136 See Art. 7 quater Model MOU (2007) and Art. 7 quater Model MOU (2014), Generic Model for Military Contingents. Cf. Deen-Racsmány, 'The Amended UN Model Memorandum of Understanding' 337 on this amendment.

137 The DPKO’s 2006 'Guidelines for Formed Police Units on Assignment with Peace Operations' (para. 24) note that all misconduct must be addressed in accordance with the 'Directives for Disciplinary Matters Involving Civilian Police Officers and Military Observers' (incorporating the 2005 amendments, see text accompanying notes 109-110, supra), "taking into consideration the authority and responsibilities of the Office of Internal Oversight Services”. The authority and responsibilities of OIOS were determined in UNGA Res 59/287 'Report of the Office of Internal Oversight Services on strengthening the investigation functions in the United Nations' (13 April 2005) GAOR 59th Session Supp 49 vol 3, 79. Cf. text accompanying notes 119-120, supra on the lack of intention to cover FPUs by these provisions.

138 Arts. 7.14-7.15 Model MOU (2014), Generic Model for FPUs.

139 Ibid., Art. 7.14. Cf. OIOS, 'Evaluation of the Enforcement and Remedial Assistance Efforts for Sexual Exploitation and Abuse by the United Nations and Related Personnel in Peacekeeping Operations' (15 May 2015) Assignment No. IED-15-001 12, Table 2, noting this problem.

${ }^{140}$ Art. 7.16 Model MOU (2014), Generic Model for FPUs and Art 7.14 Model MOU (2014), Generic Model for Military Contingents.

${ }^{141}$ Arts. 7.22.-7.23 Model MOU (2014), Generic Model for Military Contingents.

142 Arts. 7.17-7.18 Model MOU (2014), Generic Model for FPUs.
} 
not prosecute the accused FPU officer(s), the PCC is obliged to do so. The latter is also to undertake to exercise disciplinary jurisdiction if necessary. Moreover, the provisions on jurisdiction recall that in accordance with UNGA resolution $66 / 93^{143}$, the PCC is requested to extend its jurisdiction to crimes committed by its FPU officers while on mission. ${ }^{144}$

Finally, the two versions of the last provision of relevance, Article 7 sexiens on accountability, also display important differences. Admittedly, at the outset and similarly to the rules of the generic model for military contingents, the version for FPUs confirms the duty of the PCC to ensure accountability and to inform the Secretary-General of the progress made in the process of holding FPU officers accountable if justified, as well as of the final outcome of that process. Yet, the provisions of the generic version for FPUs clearly reflect the lack of PCCs' exclusive criminal jurisdiction, the more extensive rights of the UN to investigate and to adopt administrative measures in relation to FPU officers found guilty as well as the right of the host State to prosecute FPU officers. ${ }^{145}$

As stated in the Introduction of the 2014 COE Manual, this text replaces the previous edition. ${ }^{146}$ It was also taken note of by the UNGA in resolution 68/282. ${ }^{147}$ Accordingly, the

143 UNGA Res 66/93 'Criminal accountability of United Nations officials and experts on mission’ (9 December 2011) GAOR 66th Session Supp 49 vol 1, 564. In paragraph 3 of this (legally non-binding) resolution, the UNGA

[s]trongly urge[d] all States to consider establishing, to the extent that they have not yet done so, jurisdiction over crimes, particularly those of a serious nature, as known in their existing domestic criminal laws, committed by their nationals while serving as United Nations officials or experts on mission, at least where the conduct as defined in the law of the State establishing jurisdiction also constitutes a crime under the laws of the host State.

This resolution was adopted as part of the process aimed at ensuring the criminal accountability of UN officials and experts on mission (see text accompanying notes 174-176, infra). In fact, the UNGA has included such provisions in its yearly resolutions on the criminal accountability of UN officials and experts on mission since 2007 (UN Docs. A/Res/62/63 (2007), para. 3; A/Res/63/119 (2007), para. 3; A/Res/64/110 (2009), paras. 3 and 14; A/Res/65/20 (2010), paras. 3 and 15; A/Res/66/93 (2011), paras. 3 and 15; A/Res/67/88 (2012), paras. 3 and 15; A/Res/68/105 (2013), paras. 3 and 15; A/Res/69/114 (2014), paras. 3 and 15 and A/Res/70/20 (2015), paras. 7 and 21).

144 Arts. 7.19-7.20 Model MOU (2014), Generic Model for FPUs. It may be noted that in this sense the distinction between MMsNCs and FPU officers indirectly relied on by the OLA in 2004 (see text accompanying note 93, supra) is closing. Yearly reports of the Secretary-General indicate that member States are making some progress in this field (UNGA 'Report of the Secretary-General: Criminal Accountability of United Nations Officials and Experts on Mission' (11 August 2008) UN Docs. A/63/260 and (26 September 2008) Add.1; (28 July 2009) A/64/183 and (22 September 2009) Add.1; (29 July 2010) A/65/185; (25 July 2011) A/66/174 and (23 September 2011) Add.1; (31 July 2012) A/67/213; (22 July 2013) A/68/173; (30 July 2014) A/69/210; (28 July 2015) A/70/208. However, it is questionable even in relation to MMsNCs if the existence of sending State criminal justification can justify depriving the host State thereof (see text accompanying notes 171-172, infra). This amendment is thus unlikely to have practical consequences in terms of the status of FPUs and/or for the relevant competences of the UN and host States.

${ }^{145}$ See and compare Arts. 7.24.-7.27 Model MOU (2014), Generic Model for Military Contingents and Arts. 7.21-7.24 Model MOU (2014), Generic Model for FPUs.

${ }^{146}$ COE Manual (2014) 6, para. 17. In turn, the previous version (UNGA 'Manual on Policies and Procedures Concerning the Reimbursement and Control of Contingent-Owned Equipment of Troop/Police Contributors Participating in Peacekeeping Missions (COE Manual)' (27 October 2011) UN Doc A/C.5/66/8 6, para. 16) superseded the text which contained the Model MOU (2007). New MOUs are developed based on the 2014 Model (e.g. Memorandum of Understanding between the United Nations and the Government of the Republic of Serbia Contributing Resources to the United Nations Multidimensional Integrated Stabilization Mission in the Central African Republic (2 November 2015) UN Doc DFS/MINUSCA/SRB/01 $<$ http://www.parlament.gov.rs/upload/archive/files/cir/pdf/predlozi_zakona/315-16.pdf >) and the new provisions are being implemented in old MOUs as well. (UNGA 'Report of the Secretary-General: Overview of the financing of the United Nations peacekeeping operations: budget performance for the period from 1 July 2014 to 
2014 version will clearly be used for negotiating future MOUs to regulate the contribution of new FPUs.

The above provisions confirm the position that FPU officers are experts on mission for the UN, not subject to exclusive PCC jurisdiction. Yet, the C-34's 2014 annual report repeats that the determination of SEA related misconduct, "for military and police personnel, is based on investigations by troop- and police-contributing countries, as stipulated under the revised memorandum of understanding". ${ }^{148}$ This statement may indicate that the old mind-set - that FPU officers (should) enjoy protection from foreign criminal jurisdiction comparable to that granted to MMsNCs - still prevails in the Committee.

Regrettably, the 2014 amendments to the COE Manual and the Model MOU in particular have attracted little attention in academic circles, NGOs and even in the UN. The fact that since 2014 a separate generic version of the Model MOU has been available for drawing up such agreements for the contribution of FPUs has apparently not or barely been noticed outside the Organization. ${ }^{149}$ In addition, even some recent UN documents still refer to the old version of the Model MOU. ${ }^{150}$ On the other hand, recent UN instruments and documents display considerable uniformity in their treatment of FPU officers as experts on mission for the UN. ${ }^{151}$

\section{Fragile Status Quo Or Final Solution?}

The above overview of recent developments and opinions indicates that PCCs have lost several battles in relation to their appeal for equating FPU officers to MMsNCs so that the same immunities and rules concerning criminal jurisdiction would apply to them. The UN (Secretariat) appears to have been little moved by the reference in the reports of the Special Committee to the enforcement tasks of UNPOL/FPU officers in particular or by the requests to grant PCCs exclusive criminal jurisdiction over such personnel in general.

While there is much wisdom to the idiom "never say never", it is likely that the present solution represents more than just a temporary status quo. Members of the C-34 seem to have ceased to call for changes, even though they may not uniformly accept the current legal position of FPU officers. On the other hand, (recent) UN opinions, documents and instruments are very consistent, stating that FPU members (like IPOs) are experts on mission

30 June 2015 and budget for the period from 1 July 2016 to 30 June 2017' (23 February 2016) UN Doc A/70/749 Annex V 83, para. A.1.)

${ }^{147}$ UNGA Res 68/282 'Triennial review of the rates and standards for reimbursement to Member States for contingent-owned equipment’ (30 June 2014) GAOR 68th Session Supp 49 vol 3, 107.

${ }^{148}$ UNGA 'Report of the Special Committee on Peacekeeping Operations: 2014 Substantive Session', para. 67. See note 126, supra and accompanying text on the incompatibility of this formulation with existing rules.

${ }^{149}$ See e.g. <http://www.codebluecampaign.com/un-docs/>, 'Revised Model MOU', containing the old version.

${ }^{150}$ See e.g. OIOS 'Evaluation of the Enforcement and Remedial Assistance Efforts for Sexual Exploitation and Abuse by the United Nations and Related Personnel in Peacekeeping Operations' 5 and 15; M. Deschamps, H.B. Jallow, Y. Sooka 'Taking Action on Sexual Exploitation and Abuse by Peacekeepers: Report of an Independent Review on Sexual Exploitation and Abuse by International Peacekeeping Forces in the Central African Republic' (17 December 2015) <http://www.un.org/News/dh/infocus/centafricrepub/Independent-ReviewReport.pdf> 24-25; DPKO/DFS 'Guidelines on Police Command in United Nations Peacekeeping Operations and Special Political Missions' (2015) Ref. 2015.14 24; 'Guidelines on Police Operations in United Nations Peacekeeping Operations and Special Political Missions’ 27. Sed contra, e.g., Department of Political Affairs, DPKO and DFS 'Policy on Accountability for Conduct and Discipline in Field Missions' (2015) Ref. 2015.10 19, listing inter alia "Model Memorandum of Understanding between the United Nations and Police Contributing Countries for the deployment of Formed Police Units” in the references section.

${ }^{151}$ E.g. 'Policy on Accountability for Conduct and Discipline in Field Missions' para. 11.5 and documents listed in note 129 , supra. 
for the Organization, not exclusively subject to criminal jurisdiction of PCCs. ${ }^{152}$ The recent changes to the Model MOU confirm this position beyond doubt.

This outcome is not surprising in light of the fact that the similarities between FPU officers and MMsNCs are not sufficiently pronounced to justify the parallel treatment proposed by the C-34. True, FPU officers may be required to carry out (limited) enforcement tasks. However, as indicated above, ${ }^{153}$ they are only lightly armed and their enforcement tasks do not reach the level of severity that military personnel are commonly required to undertake. Admittedly, the "political sensitivities" concerning executive tasks and hence the unpopularity of such mandates ${ }^{154}$ may not have been possible to predict in the early 2000s. Yet, in hindsight, the Committee's emphasis on the need for FPU officers (or for civilian police personnel in general) to undertake enforcement measures - aimed at supporting a parallel with military personnel - appears exaggerated.

In the context of armed forces personnel, the related argument that a military commander must be able to maintain an exceptionally high level of discipline and control over the forces under his command (which could be inhibited by outside interference such as the authority of other States to exercise criminal jurisdiction its members) admittedly has some appeal. ${ }^{155}$ It may be explained for instance by reference to considerations related to the tasks and means available to such personnel (i.e. the ability and not uncommon requirement to use lethal force), the safety of the unit in extremely hostile situations and the obligations on the State to ensure that its forces do not violate international (humanitarian) law.

However, the armed forces are clearly a unique organ:

soldiers are in the category of state organs over which states exercise, or at least should exercise, the strictest control because they are entrusted with the legal capacity to use lethal force against citizens of another state. Moreover, they are trained to obey unconditionally the lawful instructions and discipline of the army. ${ }^{156}$

However, the above features commonly invoked in relation to operational necessity do not apply (quite as markedly) within police structures, rendering this justification unconvincing in relation to FPUs.

Admittedly, the fact that MMsNCs are regularly required or authorized to undertake enforcement measures and the related idea of operational necessity are not the sole justifications of TCCs' exclusive criminal jurisdiction over MMsNCs. The fact that such personnel are already subject to the military (criminal) jurisdiction of the TCC is also a prominent argument. ${ }^{157}$

\footnotetext{
152 See sources cited in notes 129 and 151, supra.

153 See text accompanying notes 35-38, supra.

154 See note 38, supra.

155 On the concepts of operational necessity and unity of command see e.g. R.J. Stanger, Criminal Jurisdiction over Visiting Armed Forces, International Law Studies 1957-1958, Navpers 15031, Vol. LII (US Government Printing Office 1965) 82-85 and sources cited there and J. Voetelink, 'Status of Forces and Criminal Jurisdiction' (2013) 60 Netherlands International Law Review 231, 244-249.

156 L. Cameron and V. Chetail, Privatizing War: Private Military and Security Companies under Public International Law (CUP 2013) 163, footnotes omitted, emphases added. The unique nature of military structures is widely acknowledged. See e.g. P. Rowe, 'United Nations Peacekeepers and Human Rights Violations: The Role of Military Discipline A Response to Dannenbaum’ (2010) 51 Harvard International Law Journal Online 69, 75; M. Zwanenburg, Accountability of Peace Support Operations (Martinus Nijhoff 2005) 106.

157 See e.g. OLA, 'Letter to the Acting Chair of the Special Committee on Peacekeeping Operations, United Nations, regarding immunities of civilian police and military personnel' 325 (arguments cited at note 93, supra), and similar statements made in the Sixth Committee of the UNGA (reproduced in the summary record of the
} 
However, on closer scrutiny, the underlying idea concerning the sufficiency of TCC (military) criminal jurisdiction for ensuring deterrence and/or accountability proves unsound even in relation to MMsNCs. ${ }^{158}$ Relevant problems (e.g. lack of extraterritorial reach) are even more pronounced in relation to police/gendarmerie codes. In addition, FPUs may even have retired police officers among their ranks to whom such codes no longer apply. ${ }^{159}$ Admittedly, the obligation imposed in the most recent version of the Model MOU to extend extraterritorial jurisdiction to FPU officers ${ }^{160}$ may bring some welcome changes in this regard. Yet, considering the lack of sufficient progress in this field in relation to MMsNCs ${ }^{161}$ and the reluctance of TCCs to prosecute and punish such personnel, ${ }^{162}$ PCC criminal jurisdiction would likely prove insufficient to ensure accountability and deterrence (and hence incapable of justifying a prohibition on host State criminal jurisdiction over FPU officers).

Last but not least, political considerations (i.e. the reluctance of States to subject members of their armed forces, a State organ par excellence ${ }^{163}$, to foreign criminal jurisdiction and the related fear that member States will not be willing to contribute sufficient troops to UN operations) are often cited in defense of exclusive criminal jurisdiction clauses. ${ }^{164}$ However, police personnel are not equally symbolically connected to the higher idea of the State as members of the armed forces are. Hence their prosecution abroad is less likely to raise equally strong sentiments (among the electorate) of sovereign rights being affected.

It must however be emphasized that the UN cannot conduct peacekeeping operations without the support of and - in this context particularly important - personnel contributions by member States. Admittedly, the Organization's resistance to providing FPU officers with the legal protection from foreign criminal jurisdiction called for by PCCs may decrease States' willingness to contribute FPUs. The pressing need to ensure sufficient personnel of a suitable quality could perceivably bring about a change in the UN's strict stance, in spite of the above observations.

relevant meetings of the Committee, e.g. UN Docs A/C.6/62/SR.6 (6 November 2007) paras. 9, 23, 34, 38, 41, 56-58, 61 and A/C.6/63/SR.5 (10 October 2008) paras. 28, 45, 61).

158 See e.g. S. Wills, 'Continuing Impunity of Peacekeepers: The Need for a Convention' (2013) 4 Journal of International Humanitarian Legal Studies 4, 51-52; F. Adaka, 'The Enforcement of Military Justice and Discipline in External Military Operations: Exploring the Fault Lines' (2008) 47 The Military Law and the Law of War Review 253; UNGA 'Report of the Secretary-General: Summary Study of the Experiences Derived from the Establishment and Operation of the Force' (9 October 1958) UN Doc A/3943, para. 137; Zs. DeenRacsmány, 'Towards A Convention on the Criminal Accountability of UN Personnel Including UN Military Experts on Mission and UN Police Officers: Whom?' forthcoming in (2015) 54 The Military Law and the Law of War Review <ssrn.com/abstract=2658027> (pre-publication version) text accompanying nn. 80-89.

${ }^{159}$ F. Hampson, 'Working Paper on the Accountability of International Personnel Taking Part in Peace Support Operations’ (7 July 2005) UN Doc E/CN.4/Sub.2/2005/42 8, para. 18.

160 See note 144 , supra.

${ }^{161}$ In relation to MMsNCs, Art. 7.22 Model MOU (2007) already imposed this requirement. In spite of this fact and of repeated calls to amend domestic legislation to enable compliance with this obligation, the extraterritorial application of criminal laws still remains a problem. See e.g. UNGA 'Report of the Secretary-General: Special Measures for Protection from Sexual Exploitation and Sexual Abuse' (14 February 2014) UN Doc A/68/756, para. 49; UNGA 'Report of the Secretary-General: Special Measures for Protection from Sexual Exploitation and Sexual Abuse’ (13 February 2015) UN Doc A/69/779, para. 58.

162 See e.g. W.J. Durch, et al., Improving Criminal Accountability in United Nations Peace Operations, Stimson Center Report No. 65, Rev. 1 (June 2009) xii and Deen-Racsmány, 'The Amended UN Model Memorandum of Understanding' 340.

${ }^{163}$ In 1935, the Military Court of Rome referred to "the undisputed principle that armies [are] the supreme expression of the force upon which the sovereignty of a State is founded”. In re Polimeni [1935-1937] Ann. Dig. No. 101248.

164 See e.g. D.W. Bowett, United Nations Forces: A Legal Study of United Nations Practice (Stevens 1964) 438, 440; UNGA 'Report of the Secretary-General: Summary Study of the Experiences Derived from the Establishment and Operation of the Force', paras. 136 and 163. 
Auspiciously, according to UN statistics, the amount of police personnel seconded by member States to participate in UN peacekeeping operations has increased rather than decreased since the publication of the 2014 amendments to the Model MOU. ${ }^{165}$ In addition, while police contributions are frequently criticized for being of an inadequate quality, ${ }^{166}$ since $2008,{ }^{167}$ the UN has been actively working on measures to ensure sufficient contributions of a suitable standard. ${ }^{168}$

At the same time, the UN is increasingly forced to give priority to accountability over quantity. In response to new revelations in 2015 and 2016 of large scale SEA by UN peacekeepers, ${ }^{169}$ the Secretary-General proposed inter alia to repatriate entire military units and FPUs where evidence shows widespread SEA by such personnel. In 2016, the Security Council approved this proposal. Moreover, it requested the Secretary-General to replace (military and/or police) units contributed by a State with units from another member State if the contributing State has failed to abide by its obligations to investigate such allegations and/or prosecute the perpetrators and/or to inform the UN on the measures taken in this regard. ${ }^{170}$

165 See sources cited in note 3, supra.

166 See W.J. Durch, United Nations Police Evolution, Present Capacity and Future Tasks, GRIPS Policy Research Center Discussion Paper: 10-03 (Tokyo, 10 March 2010) 13-14. See also F. van der Laan et al, The Future of Police Missions, Clingendael Report (February 2016) $<$ http://www.clingendael.nl/sites/default/files/the_future_of_police_missions.pdf $>53$ noting that

[n]otwithstanding the need for other capacity and criticism of the use of FPUs by analysts, interviewees mentioned that the United Nations does not have adequate FPU capacity due to the limited ability of countries to contribute such units in a timely manner. Yet, it is important that issues of behaviour and performance are addressed, as they can affect and destroy progress in other areas. Quality over speed and quantity applies here.

Problems related inter alia to quality of equipment, performance, recruitment and training have also been recognized in Johnson, et al 'External Review of the Functions, Structure and Capacity of the UN Police Division' 19-23, 28, 30.

167 The problem was identified in 2008 through an internal review of the Police Division, confirmed by an independent review in 2011 (UNGA 'Identical letters dated 18 February 2011 from the Secretary-General addressed to the President of the General Assembly and the President of the Security Council' (22 February 2011) UN Doc A/65/747-S/2011/85, para. 34 (a)).

${ }^{168}$ Measures adopted so far include the development of a new FPU doctrine as well as training requirements and employment of mobile training teams (see Hansen, 'Policing the Peace: The Rise of United Nations Formed Police Units' 4; UNGA 'Report of the Secretary-General: United Nations police', paras. 51-70), followed by the launch of the "Stand-by FPU Capacity Initiative" by the DPKO in 2013. This stand-by arrangement, meant to raise the availability of FPUs for rapid deployment through financial incentives, is hoped to "broaden the current pool of PCCs providing FPUs.” (Van der Laan et al, The Future of Police Missions 45.) Finally, the most recent developments concern the implementation of the police strategic guidance framework and the initiation of an external review of UN police (UNGA 'Report of the Secretary-General: The future of United Nations peace operations: implementation of the recommendations of the High-level Independent Panel on Peace Operations' para. 93). The latter identified a great number of (fundamental) problems and weaknesses in relation to UNPOL in 2016 and presented recommendations to address those, calling even for a "paradigm-shift" (Johnson, et al 'External Review of the Functions, Structure and Capacity of the UN Police Division', see in particular 12-15).

A not insignificant share of the report's findings and recommendations address specifically FPUs (e.g. ibid, paras. 8, 54, 63, 64, 73, 90,112, 150, 166, 173), including even a proposal for the Secretary-General to "[c]ommission a comprehensive, in-depth and independent review of Formed Police Units" (ibid., para. 189). However, while the review also involved questions of accountability (in relation to the mission/UN) (see in general ibid., paras. 122-137 and in relation to FPUs ibid., paras. 126, 128, 134, 135), no observations or recommendations presented in the report pertain to FPU (or UNPOL) officers' status or criminal accountability. ${ }^{169}$ See reports at $<$ http://www.codebluecampaign.com/latest-news/>.

${ }^{170}$ UNSC Res 2272 (2016) 'United Nations peacekeeping operations' (11 March 2016) UN Doc S/RES/2272, (2016) paras. 1-2. See also Secretary-General 'Special Measures Report' 2016, paras. 25 (referring to a decision by DPKO a and DFS to "repatriate[e] and terminat[e] the deployment of all military personnel from a Member 
The 2015-2016 SEA scandal has produced another relevant effect: the SOFA principle of exclusive TCC criminal jurisdiction over MMsNCs has been called into question by experts, recommending the UN to "[n]egotiate with TCCs provisions ensuring prosecution, including by granting host countries subsidiary jurisdiction to prosecute crimes of sexual violence by peacekeepers". ${ }^{171}$ These recommendations have been taken note of by the Secretary-General in his 2016 Report on 'Special Measures for Protection from Sexual Exploitation and Sexual Abuse'. He voiced commitments to consult with member States on this issue while noting that "[t]his proposal would require extensive legislative changes and General Assembly approval". ${ }^{172}$ In the face of the long prevailing attitude of TCCs, that process is likely to be lengthy and burdensome, requiring a great deal of tact. Yet, the consistent attitude of the UN (Secretariat) described in this paper (i.e. rejecting all attempts at extending exclusive contributing State jurisdiction to FPUs) may be taken to suggest that faced with SEA scandals affecting its credibility the UN is ready to consider this options seriously.

In turn, these developments (in relation to FPUs and MMsNCs) are likely to prove mutually reinforcing. The above measures and recommendations indicate that the foundations of the so far seemingly "sacred" SOFA rule on exclusive criminal jurisdiction are shaking. Now that the principle becomes subject of debate even in relation to MMsNCs, ${ }^{173}$ it appears inconceivable that the UN would be prepared to grant FPU officers such an extensive protection from foreign criminal jurisdiction.

There is however still a small chance of future conflicting signals concerning the status and criminal accountability of FPUs, as a consequence of the UN project on the accountability of UN officials and experts on mission. ${ }^{174}$ In response to the 2005 SEA scandal, the first Group of Legal Experts recommended the conclusion of a convention on this subject. ${ }^{175}$ The issue and the draft convention prepared by the GLE have been on the agenda of the UNGA's Sixth Committee since then, without much progress. Significantly, one of the stumbling blocks has been the question what personnel categories should be covered. In the past, several delegations proposed that military and police experts on mission (including IPOs and FPU officers) should be excluded, for the reason of them being covered by the criminal jurisdiction of the seconding/contributing States. ${ }^{176}$

However, there appear to be no legal obstacles in the way of including such personnel under the planned convention, along the lines proposed by the GLE. ${ }^{177}$ In addition, members of the Sixth Committee appear to have ceased their calls for the exclusion of military and police experts on mission (a major share of the potentially covered personnel) from the Convention. ${ }^{178}$

State” in the Central African Republic) and 60. This example demonstrates the UN's resolve. See also Johnson, et al 'External Review of the Functions, Structure and Capacity of the UN Police Division', para. 136, calling for naming and shaming in this context.

171 'Taking Action on Sexual Exploitation and Abuse by Peacekeepers’ 88, Recommendation \#8.) See also ibid. 87-88.

172 Secretary-General 'Special Measures Report’ 2016, para. 97.

${ }^{173}$ It may be noted that international law does not require States to recognize the exclusive criminal jurisdiction of sending States, even in relation to military personnel. See on this issue Zs. Deen-Racsmány, "Exclusive” Criminal Jurisdiction over UN Peacekeepers and the UN Project(s) on Criminal Accountability: A Self-Fulfilling Prophecy?' (2014) 53 The Military Law and the Law of War Review 247.

${ }^{174}$ As a result of this process, the UNGA has adopted several resolutions on the subject. See note 143, supra.

175 GLE Report.

176 See note 157 , supra.

177 See e.g. Deen-Racsmány, 'Towards A Convention on the Criminal Accountability of UN Personnel Including UN Military Experts on Mission and UN Police Officers: Whom?’.

178 The author has not been able to identify such statements in the meeting records of the Sixth Committee from 2011 onwards. 
Yet, as the UN has limited means to influence the contents of such an international convention, there is still a slight chance - if consensus is reached on the contents of a convention at all ${ }^{179}$ - that FPU officers may not end up being covered, or that the competences granted to sending and host States in relation to them would not be identical to the existing UN regime. Even though such a solution could (re)introduce confusion concerning the status of and rules applicable to FPU personnel - a clearly objectionable outcome -, the planned international convention could at any event not (directly) affect UN rules and regulations currently in force, nor the rights and obligations of the UN in relation to such personnel without the Organization's approval. ${ }^{180}$

\section{Conclusions and Lessons Learned}

Having briefly examined the origins of formed police units and their role and position in UN missions, we endeavored to identify the current regulation of the status and criminal accountability of FPU officers through a study of the decade-long struggle between the Special Committee on Peacekeeping Operations and the UN (Secretariat). The following main conclusions concerning their status and criminal accountability emerged as a result of the overview of applicable rules and relevant developments:

- FPU officers are experts on mission for the UN, enjoying the immunities laid down in Article VI of the CPIUN;

- they thus enjoy immunities ratione materiae; but

- they are, unlike MMsNCs, not covered by SOFA provisions granting contributing States exclusive criminal jurisdiction over the personnel placed at the UN's disposal. Accordingly,

- they are not exempt from foreign criminal jurisdiction for their private conduct; and

- $\quad$ they may be subject to the criminal jurisdiction of the host State following waiver by the Secretary-General or certification that the conduct in question was not committed in an official capacity.

- The UN has disciplinary authority over them in accordance with the 'Directives for Disciplinary Matters Involving Civilian Police Officers and Military Observers’; and

- the UN and the host State possess investigative powers in relation to them for crimes and misconduct committed by them while assigned to a UN mission.

These principles derive from and/or are confirmed, inter alia, in the UN Model SOFA (and in provisions of SOFAs modelled after that document), the 'Directives for Disciplinary Matters Involving Civilian Police Officers and Military Observers', the 'Regulations

\footnotetext{
${ }^{179}$ In the past years, several member States expressed the position in the Sixth Committee that the conclusion of a convention along the lines proposed by the GLE was not necessary or would be premature. See e.g. UN Docs. A/C.6/69/SR.17 (10 November 2014), paras. 3, 30, 39 and A/C.6/67/SR.8 (12 October 2012), paras. 94, 103. Sed contra (supporting a convention), e.g., A/C.6/67/SR.8 (12 October 2012), paras. 82, 86, 97 and 98. In 2016 following the 2015-2016 SEA scandal - the Secretary-General strongly recommended member States to continue their efforts towards finalizing such an agreement (Secretary-General 'Special Measures Report' 2016, para. 66) and in 2014 and 2015 the UNGA invited member States to comment on the GLE report and on (suitable) future action. See resolutions cited in note 143, supra.

180 The amendment of the rules and regulations adopted by the UN would have to follow the rules and procedures prescribed for such an amendment within and by the Organization itself. In turn, the rights of the UN are protected under the customary norm of the law of treaties (codified also in Article 34 of the Vienna Convention on the Law of Treaties between States and International Organizations or between International Organizations (adopted 20 March 1986, not yet entered into force) (1986) 25 ILM 543), flowing from the principle pacta tertiis nec nocent nec prosunt.
} 
Governing the Status, Basic Rights and Duties of Officials other than Secretariat Officials, and Experts on Mission', various UN policy instruments ${ }^{181}$ and last but not least the recently once again - amended UN Model MOU (specifically the generic version for FPUs). While the C-34 initially won a significant battle, ${ }^{182}$ it subsequently lost the war: under the legal regime currently in force, the legal position and criminal accountability of FPU officers is identical to that of IPOs (experts on mission) in all relevant respects, showing no resemblance to the rules applicable to MMsNCs.

Considering the existence of pertinent dissimilarities between MMsNCs and FPU officers, it is unlikely that further attempts within the UN by (members of) the C-34 to have the rules concerning the status and/or the criminal accountability of FPUs amended would be successful. This impression is underscored by recent calls within the UN for initiating negotiations with TCCs to permit host State criminal jurisdiction even over MMsNCs.

The process described in the present study has significant implications concerning the likely outcome of this proposed change in relation to MMsNCs. The UN's averse attitude to granting PCCs exclusive criminal jurisdiction over their FPU personnel suggests that the Organization may be inclined to support such a reform. On the other hand, the persistence of (members of) the Special Committee on Peacekeeping Operations in relation to FPUs is telling. Their decade-long quest for exclusive contributing State criminal jurisdiction over FPU officers renders it very clear that the C-34 will not easily give up that privilege in relation to MMsNCs. At the very least, the idea will likely take some time to get used to. Yet, the experience related to FPUs indicates that there is hope. The main question appears to be whether a sufficient number of TCCs will remain ready to contribute troops - even if their military personnel is not exempted from host State criminal jurisdiction - to guarantee the continuity of ongoing and future operations in the short term, while others win time to adjust their current mindset (and relevant domestic statutes) to the change.

Next to the above findings and conclusions, the present study teaches us another important lesson. The analysis has revealed that the regulation of the status and criminal accountability of FPU officers is crystal clear. It is not the rules themselves but their amendment and, even more importantly, the failure of the UN and other actors in the field to adapt relevant documents, instruments and information materials and to promptly make up-todate information available that has contributed to ambiguity. As long as the presentation of the rules is not transparent, uniform and clear, the legal situation may remain open to interpretation, debate, and, in a worst case scenario, even to abuse. It must therefore be emphasized that facilitation of easy access to up-to-date and accurate (legal) information by the UN would likely improve the accountability of its personnel and could thus contribute to the restoration of the Organization's credibility.

\footnotetext{
181 See e.g. documents cited in note 151, supra.
}

182 See text accompanying notes 87-88, supra. 